\title{
Article \\ Changes in the Country and Their Impact on Topographic Data of Agricultural Land-A Case Study of Slovakia
}

\author{
Zofia Kuzevicova $^{1}\left(\mathbb{D}\right.$, Diana Bobikova ${ }^{1}$, Stefan Kuzevic ${ }^{2, *(D)}$ and Samer Khouri ${ }^{2}$ (D) \\ 1 Faculty of Mining, Ecology, Process Control and Geotechnology, Institute of Geodesy, \\ Cartography and Geographical Information Systems, Technical University of Kosice, Letna, 9, \\ 04200 Kosice, Slovakia; zofia.kuzevicova@tuke.sk (Z.K.); diana.bobikova@tuke.sk (D.B.) \\ 2 Faculty of Mining, Ecology, Process Control and Geotechnology, Institute of Earth Resources, \\ Technical University of Kosice, Letna, 9, 04200 Kosice, Slovakia; samer.khouri@tuke.sk \\ * Correspondence: stefan.kuzevic@tuke.sk
}

check for updates

Citation: Kuzevicova, Z.; Bobikova, D.; Kuzevic, S.; Khouri, S. Changes in the Country and Their Impact on Topographic Data of Agricultural Land-A Case Study of Slovakia. Land 2021, 10, 1208. https:/ / doi.org/10.3390/land10111208

Academic Editors: Hamed Olfat, Abbas Rajabifard and Behnam Atazadeh

Received: 11 October 2021 Accepted: 3 November 2021 Published: 8 November 2021

Publisher's Note: MDPI stays neutral with regard to jurisdictional claims in published maps and institutional affiliations.

Copyright: (c) 2021 by the authors. Licensee MDPI, Basel, Switzerland. This article is an open access article distributed under the terms and conditions of the Creative Commons Attribution (CC BY) license (https:/ / creativecommons.org/licenses/by/ $4.0 /)$.

\begin{abstract}
Due to natural phenomena as well as human activities, changes are occurring in land use. Techniques and environment GIS have made it possible to process large amounts of data from various sources. In Slovakia, mapping of topography and elevation is being carried out as part of the elaboration of land readjustment projects. This is also a starting point for updating estimated pedologic-ecological units (EPEUs). Therefore, it is necessary to make efforts to harmonize the real state of the country with the data stored in the EPEU database, which are the basis for spatial analyses in the country and the creation of price maps. The EPEU system was built in the 1970s; however, only after 1990, due to changes in ownership and user conditions of the land, did it begin to seriously address the issue of updating data. This study examines selected sources of altimetry data, especially airborne laser scanning (ALS), and their potential role in processing purpose maps and harmonizing boundary curves and slope and exposure characteristics at a stable 5-position EPEU local code. Based on the obtained results, the use of ALS data and the Digital Terrain Model (DTM) derived from them may lead to the streamlining of some processes in terms of planning and decision-making regarding land use, even outside the context of the ongoing land reforms in the Slovak Republic.
\end{abstract}

Keywords: land policy; ALS; GIS; slope; exposure

\section{Introduction}

The priorities of European Union (EU) policies are sustainability and rural development, as expressed in the preparation of the common agricultural policy after 2020 under The European Network for Rural Development (ENRD) (https:/ / enrd.ec.europa.eu, accessed on 15 September 2021). The need for effective implementation of the necessary measures to achieve stable soil protection for its sustainable development is also articulated in the Thematic Strategy for Soil Protection [1]. In line with the United Nations Agenda [2], the challenge is to ensure the sustainability of ecosystems worldwide and the implementation of agricultural processes by 2030 to maintain soil while improving its quality.

The European new growth strategy is based on the European Green Deal [3]. It is concerned with environmental sustainability issues in a broader sense, including the protection and optimization of natural resources and land as a basis of livelihoods. In the context of the COVID-19 pandemic, European countries need to adjust their approach to creating the conditions for environmental protection and ecology, and in so doing, pay increased attention to the digitization process in terms of data quality. Targets were set in the so-called Recovery Plans (NextGenerationEU) [4], where Member States agreed to set the goals of improving and restoring valuable potential for future generations. The Slovak Recovery Plan [5] was approved by the European Commission and presents a clear vision for the next decade, also in terms of land consolidation. 
In many countries, users of agricultural land are considered to be individuals who arbitrarily interfere with land structures, and in so doing, frequently violate legislation. According to [6], a clear definition of the relationship between owners and agricultural land is needed, as this relationship significantly affects its quality in the future, regardless of the ongoing process of land consolidation (LC) in EU countries. The authors of [7] point out the problems related to comparing the effectiveness of land improvements in different countries. Improving economic efficiency and streamlining land use [8] were the impetus for the implementation of LC. The Slovak Republic has been trying for several years to implement LC according to Act No. 330/1991 Coll. on land consolidation [9].

Harmful human interventions on the landscape and negative side effects from human activities [10] bring about soil change over time. Additionally, data on spatial boundaries change, and their impact in secondary anthropogenic stress phenomena is shown in the disruption of ecosystems [11]. This situation is also influenced by historical development as a result of human activities, in which period of the political establishment, primarily in the post-communist countries, among which Slovakia is included. Large-scale land management, planned farming, and mining [12] have brought about irreversible changes in agricultural land, significantly reducing its quality.

Remote sensing methods are currently being used to map the structure of, and changes to, the landscape. The work of Friedl et al. [13] deals with country mapping using MODIS data at regional and global levels. Another source of landscape mapping data is Landsat [14-16], which makes NDVI and SSIC analyses possible when used in combination with Google Earth images [17] or the Google Earth Engine platform [18,19]. Orthophotos from UAVs are used in cadastral mapping to capture objects and changes in the landscape in more detail [20]. LiDAR is applied to monitor landslides on agricultural land [21].

For precision agriculture applications, large amounts of data are needed on soil characteristics, as well as on land relief (e.g., slope, aspect, curvature) [22]. This information could be a starting point for decision making regarding local land-use methods. Remote Sensing and Unmanned Aerial Vehicles (UAVs) are key sources of such information [23]. A case study by Seeruttun and Crossley [24] showed the usefulness of DTM as a source of data for planning, but also pointed to the need to pay attention to the accuracy of terrain models. Digital terrain models provide source data for spatial analyses, and can also serve as the basis for the creation of derived maps. One study [25] confirmed the effect of topography on soil erosion and slope-varying soil properties, and emphasized the need to take microreliefs into account.

In Slovakia, each plot is characterized by its properties, which are expressed through estimated pedologic-ecological units (EPEUs). Based on these units, the value of land comprising agricultural land and other terrain may be determined [26].

The building of a comprehensive information system of soil values in Slovakia began to take shape in the period of collectivisation [27] and the association (according to the Act No. 49/1959 Coll. on Unified Peasant Cooperatives) of agricultural land in the period of Czechoslovakia, with the aim of evaluating of the productive capacity of agricultural soils.

In the period of 1961-1970, a detailed comprehensive soil survey (CSS) of agricultural soils was undertaken, which laid the foundation [28] for the construction of a new soil value information system (SVIS).

The focus of the mapping was agricultural land, notably in the rural areas of the municipalities bounded by areas of homogeneous soil and ecologically homogeneous EPEU units. The land types [28] were categorized as arable, hops, vineyards, permanent grassland or orchards in the framework of the registry of land production potential.

Due to the changes in land ownership-user relationships in postcommunist countries (after 1990 and the subsequent breakup of Czechoslovakia), more sophisticated procedures began to be legislated in Slovakia. They consisted mainly of the implementation of more precise parameters regarding the accuracy of the EPEU. At the same time, a minimum area 
of 0.25 ha was established, in accordance with an adjustment to the seven-digit EPEU code implemented in the national legislation.

Most agricultural land in Slovakia is leased to entities that manage it in the form of larger units. Ownership rights to this land are registered in the information system of the Cadastre of Real Estate in the so-called legal state (designated documentation), which can currently, land ownership can be characterized as fragmented [29].

In most EU Member States, agricultural rental has been and remains a common trend [30]. Rental relationships between landowners and tenant are dynamic. In terms of different legislation, each country has sought to improve the situation by introducing processes related to the arrangement of ownership, such as LC projects [31], following the present time land management under the allocated EU subsidies [32].

In addition to interpretations of the value of the EPEU, economic elements and thus precise categorizations of land managers are, for the purposes of subsidies, also important.

Capturing change is a significant part of land-use decision-making processes. As part of land improvement efforts in Slovakia, the mapping of elevation is also underway. The present research focuses on the possibility of using existing digital terrain models for the creation of purpose maps, as well as the need to harmonize data regarding boundaries, slope and exposure at a stable, five-position local code EPEU. The methodology takes into account changes that took place in the country over several decades. An area where landscaping had not yet taken place was chosen as the study area. The analysis of the area was based on available data on EPEU, airborne laser scanning, and DTM 3.5 and 5.0. Data processing and output creation were performed in ArcGIS Pro 2.7.0.

\section{Materials and Methods}

\subsection{Study Area}

The cadastral unit of Podrečany with an area of 1160.48 ha, located in the district of Lučenec (Figure 1), was chosen for the study. The altitude ranges from 200 to $602 \mathrm{~m}$. According to the climate classification that Konček [33] prepared for the period of 1961-2010, the area is classified as "warm" with T2 (warm, dry with mild winters), T4 (warm, slightly dry with mild winters), and T7 (warm, slightly humid with cold winters) subregions. The average monthly air temperatures are -2 to $-3{ }^{\circ} \mathrm{C}$ in January and $20^{\circ} \mathrm{C}$ in July. According to the Slovak Hydrometeorological Institute, the average annual total precipitation is in the range of $550-600 \mathrm{~mm}$. In the winter months, there is snow cover in the locality.

Most of the territory of the Lučenec basin and the valleys of the surrounding mountains, to which the cadastral unit of the village of Podrečany also belongs, represent large-scale arable land management. Agricultural land is intensively used, sometimes comprising drained wetlands. Cereals (wheat), root crops (potatoes, sugar beet, and maize), industrial crops (flax and rape), and fodder (red clover, pulp, and silage) are grown in the selected area. Cultural meadows and clover are predominant in meadows and pastures. Beeches and oaks are widespread in the forested area.

Soil type characteristics, which are the basic identification unit for the morphogenetic and agronomic categorization of soils, are based on EPEU. The study site is mainly characterized by dystric cambisols and cambic umbrisols, albic luvisols and eutric fluvisols, and dystric planosols. A basic description of the main soil units (MSUs), as well as information on the area of MSUs within the cadastral unit, is presented in Table 1. 


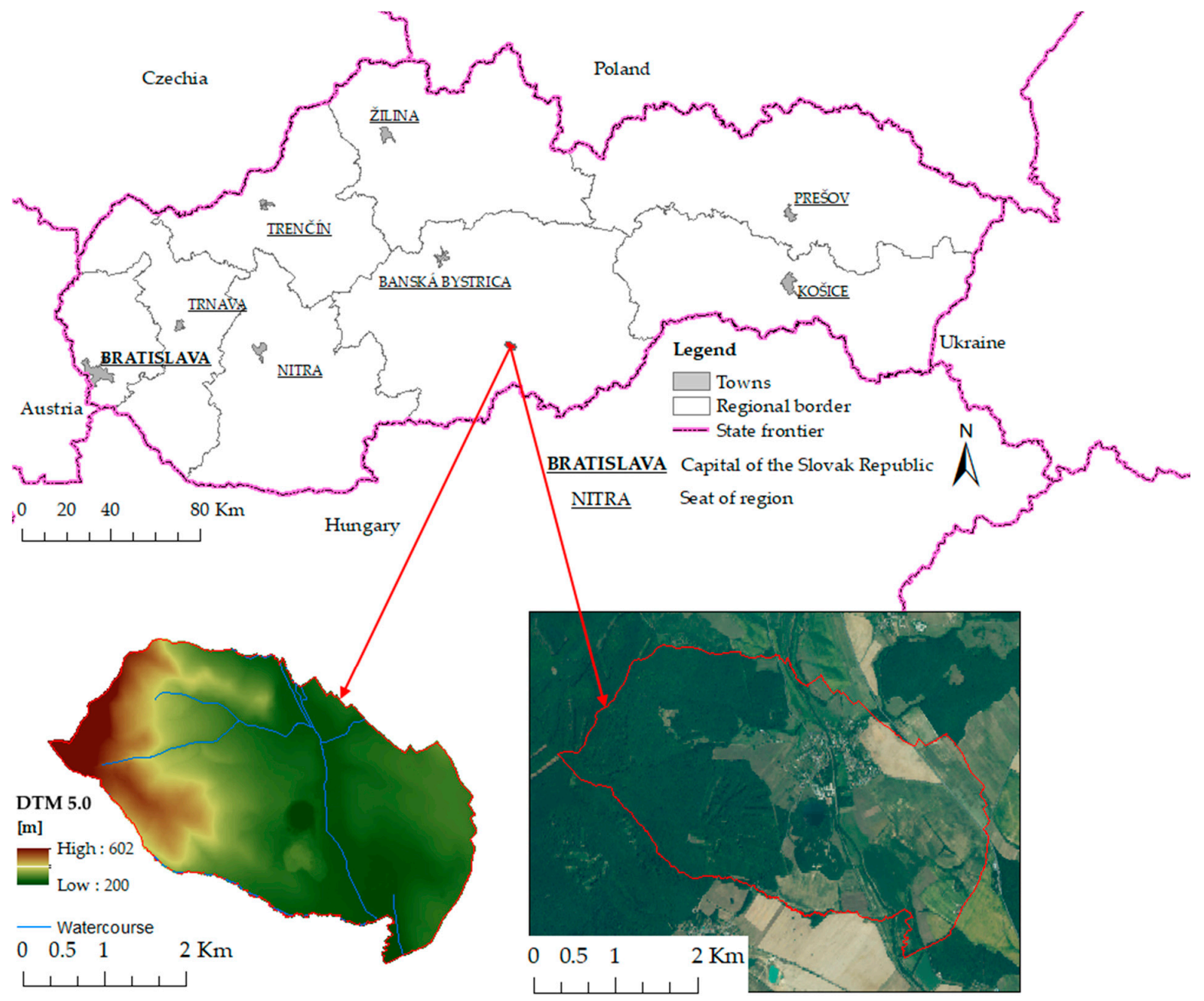

Figure 1. Study location cadastre unit of Podrečany.

Table 1. The main soil units according to EPEU.

\begin{tabular}{|c|c|c|c|c|}
\hline MSU Code & Signature & Characteristics & Area (ha) & Area $(\%)$ \\
\hline 11 & $\mathrm{FMa}_{\mathrm{G}}$ & Eutric Fluvisols, gleyic, medium heavy, local arenic & 97.93 & 8.44 \\
\hline 56 & LMag-PGal & $\begin{array}{l}\text { Albic Luvisols to Stagnic Glossisols from loess } \\
\text { and polygenetic loams, in the surface horizon medium heavy }\end{array}$ & 122.49 & 10.55 \\
\hline 57 & PGa & $\begin{array}{l}\text { Eutric to Dystric Planosol, from loess and polygenetic loams, } \\
\text { in the surface horizon medium heavy to heavy, local very heavy }\end{array}$ & 102.08 & 8.80 \\
\hline 60 & $\mathrm{KMa}^{\mathrm{a}}$ & $\begin{array}{c}\text { Dystric Cambisols and Cambic Umbrisols, acid to distinctly acid, } \\
\text { from the weathering products of crystalline rocks, } \\
\text { medium heavy to arenic }\end{array}$ & 110.62 & 9.53 \\
\hline 65 & KMm, KMI & $\begin{array}{c}\text { Cambisols and Luvisols Cambisols on slope loam, } \\
\text { medium heavy to heavy }\end{array}$ & 86.47 & 7.45 \\
\hline 79 & $\mathrm{KMa}(\mathrm{m}), \mathrm{RNk}$ & $\begin{array}{l}\text { Eutric Cambisols to Dystric Cambisols with Leptosols, } \\
\text { with shallow covers, from other substrata, medium heavy to arenic }\end{array}$ & 25.60 & 2.21 \\
\hline 83 & $\mathrm{KMm}$ & $\begin{array}{l}\text { Eutric Cambisols from other substrata on significant slopes: } \\
\qquad 12-25^{\circ} \text {, medium heavy to heavy }\end{array}$ & 21.58 & 1.86 \\
\hline \multirow[t]{3}{*}{85} & \multirow[t]{3}{*}{ LMag-PGal } & $\begin{array}{l}\text { Albic Luvisols to Stagnic Glossisols to Eutric Planosols, luvisols, } \\
\text { from polygenetic loams associated with skeleton, medium heavy }\end{array}$ & 11.23 & 0.97 \\
\hline & & built-up area & 61.21 & 5.27 \\
\hline & & Without EPEU & 521.29 & 44.92 \\
\hline Total & & & 1160.48 & \\
\hline
\end{tabular}

${ }^{a}$ most subspecies of agricultural land plowed to a depth of $0.35 \mathrm{~m}$. 


\subsection{Soil Value Information System (SVIS)}

A number of GISs on soil have been created for the use and arrangement of agricultural land, monitoring its changes, and processing information about its properties in Slovakia.

Currently, SVIS and agricultural soil monitoring are the most frequently used sources of information on soils. Associated data are available for the government, institutions belonging to the Ministry of the Environment, government departments, and public administration [34].

SVIS data are shown in Figure 2, which also displays selected sets of data and map products from information subsystems belonging to other state departments.
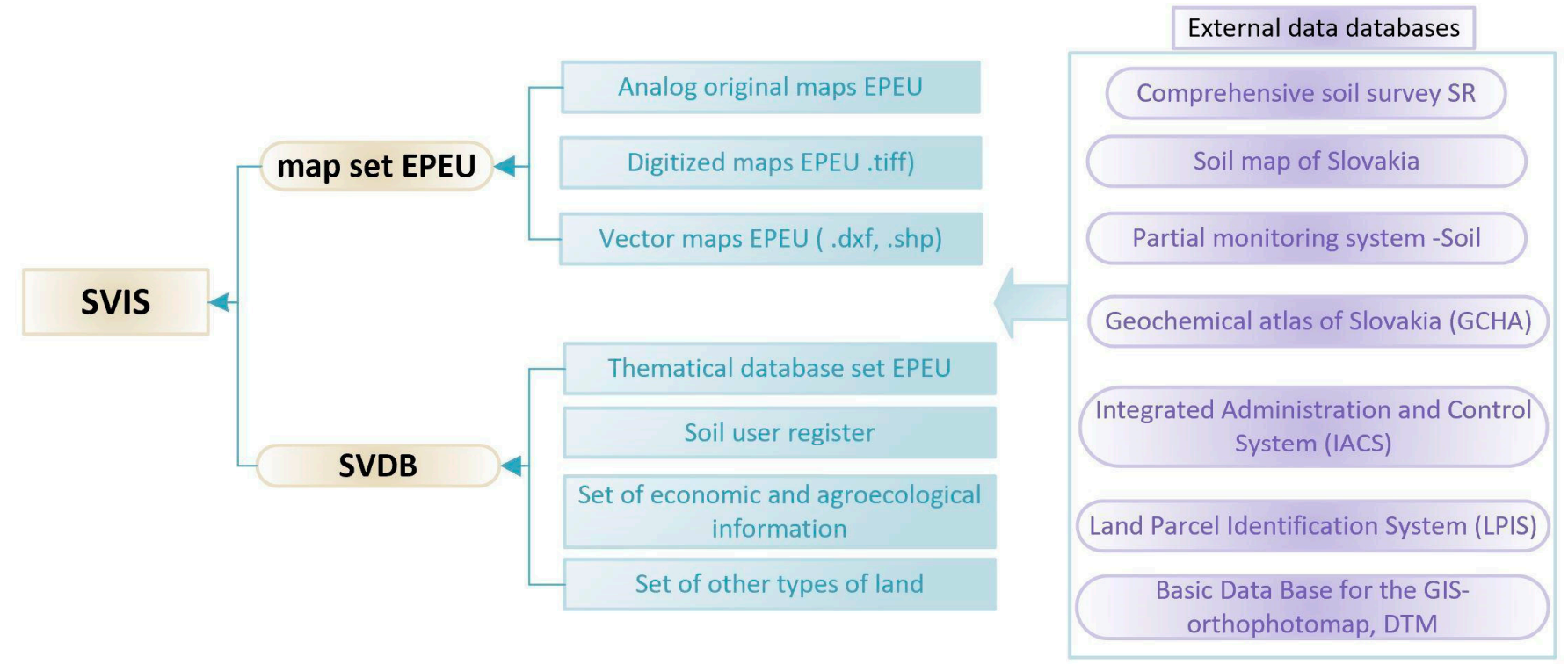

Figure 2. Soil value information system structure.

A reputable data bank (SVDB- soil value data bank) [35] has become a part of SVIS (soil value information system), which is constantly being updated. It contains data on all soil properties expressed by the EPEU code, and together with a set of useful databases has come to define the taxonomic levels of soil-ecological units.

The SVIS also contains data on all EPEU according to the registry of users, and to the cadastral units of municipalities and higher territorial units of the administrative division of the state. Additionally, it includes economic and agroecological information, and information on special types of land according to anthropogenic activities. This database is managed by the National Agricultural and Food Center (NAFC)-Research Institute Agricultural and Food Economics.

The genetic characteristics of soils (granularity, skeletonisation, soil depth), climate (temperature and precipitation conditions, potential evaporation) and relief (slope and exposure) are taken into account in descriptions of EPEU areas.

The technical basis for the the current boundaries of the EPEU are vector maps, which were created by digitizing original maps (which were themselves based on the State Map, derived at a scale of 1:5000) during EPEU mapping from 1972 to 1981. At present, the database does not contain current data altitude and topographic data for the entire territory of the Slovak Republic which is a needed for the specification of the EPEU boundaries on agricultural land.

Registration of data in the form of boundaries and codes for individual areas to the Cadastre of the Slovak Republic began after 1995, at which time a registry was created of renewed land records which also included EPEU vector maps submitted in the vector graphic interface $\left({ }^{*} . v g i\right)$ format. Currently, updates to the registered EPEU boundaries serve well in resolving land consolidation (LC) issues in individual cadastral areas, where part of the 
performed geodetic work has involved mapping topography and elevation by direct field measurements and the subsequent use of data from ALS and orthophotomosaics.

As a result of the processing of soil data in individual regions, the soil ecological unit system, i.e., EPEUs with a seven-digit alphanumeric code, were introduced in 1996. (Figure 3).

\begin{tabular}{|c|c|c|c|c|}
\hline \multicolumn{5}{|c|}{ EPEU CODE STUCTURE } \\
\hline \multicolumn{2}{|c|}{ Main soil- climate unit } & & & \\
\hline Climate region & Main soil unit & Slope-Exposure & Skeleton-Depth Soil & Granular Soil \\
\hline$x \times$ & $x \times$ & $\mathrm{x}$ & $\mathrm{x}$ & $\mathrm{X}$ \\
\hline $00-10$ & $00-99$ & $0-9$ & $0-9$ & $1-5$ \\
\hline
\end{tabular}

Figure 3. EPEU code structure.

The area of the EPEU is currently affected by the following factors:

(1) LC in the initial documents (EPEU update, value maps) [36] in accordance with the approved methodology and Act. No. 330/1991 Coll. On the Landscape Consolidations, Land Ownership, Land Offices, Land Fund and Land Associations, as amended [9].

(2) significant changes in the territory, following the initiative of the soil service or at the request of the landowner Act No. 220/2004 Coll. No 245/2003 Coll. on integrated pollution prevention and control, and on the amendment to and supplementation of certain acts (Soil Protection Act) [37].

(3) The occupation of agricultural land for nonagricultural purposes (permanent change) Soil Protection Act and Act No. 162/1995 Coll. on the cadastre of real estate and on the registration of ownership and other rights to immovable property, as amended (Cadastral Act) [38].

\subsection{Input Data}

Data from airborne laser scanning (* .las), Digital Terrain Model (DTM 3.5, DTM 5.0) and aerial photogrammetry ( ${ }^{*}$.tiff) were used as input data. To display the EPEU borders, data in vector form from the cadastre of real estate information system were used, as these are considered reliable and legally binding [34] (\$7). All source data were provided by the Geodesy, Cartography, and Cadastre Authority of the Slovak Republic (GCCA SR). The data were then processed in a GIS environment.

The Digital Terrain Model (DTM 5.0) was created based on aerial laser scanning data, which took place at the site in the period of November 2018 to April 2019. The absolute vertical accuracy of the obtained cloud points in the coordinate system (ETRS89-h) was $0.03 \mathrm{~m}$, the positional accuracy of cloud points (ETRS89-TM34) was $0.11 \mathrm{~m}$, and the average density of the points of the last reflection was $19 \mathrm{~b} / \mathrm{m}^{2}$. The altitude accuracy of DTM 5.0 in ETRS89-h, created from ALS data, was $0.03 \mathrm{~m}$. The size of the raster cell was $1 \times 1 \mathrm{~m}$.

The Digital Terrain Model (DTM 3.5) is based on DTM3 (DTM3 was created by vectorizing the elevation of topographic maps of scale 1:10,000, or of scale 1:25,000) and was supplemented by remodeling the plains, basins, and valleys of large rivers. To this end, photogrammetric data collected for ZB GIS were also applied. The result was a raster model with a resolution of $10 \times 10 \mathrm{~m}$.

The collection of orthophotomosaic images took place in 2018. The images had a resolution of $25 \mathrm{~cm} /$ pixel and an accuracy of RMSExy $=0.30 \mathrm{~m}$, CE90 $=1.5175 \times$ RMSExy $=0.45 \mathrm{~m}$ and CE95 $=1.7308 \times$ RMSExy $=0.52 \mathrm{~m}$.

Map portals which illustrate the EPEU layer are available to the public (Figure 4):

- Soil portal under the jurisdiction of the National Agricultural and Food Center (NAFC), and

- the ZB GIS (Basic database for geographic information systems) map client as an agro layer. 


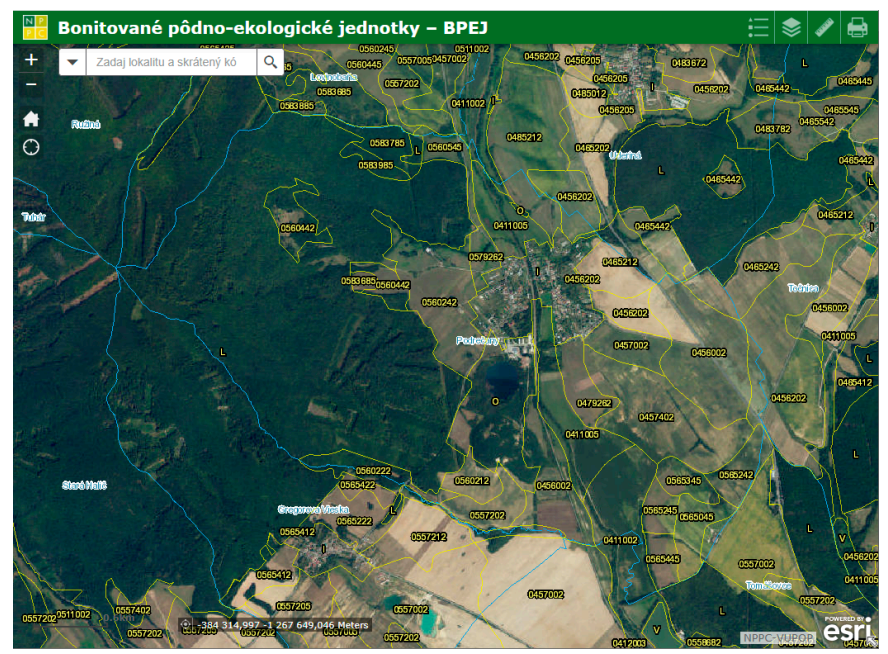

(a)

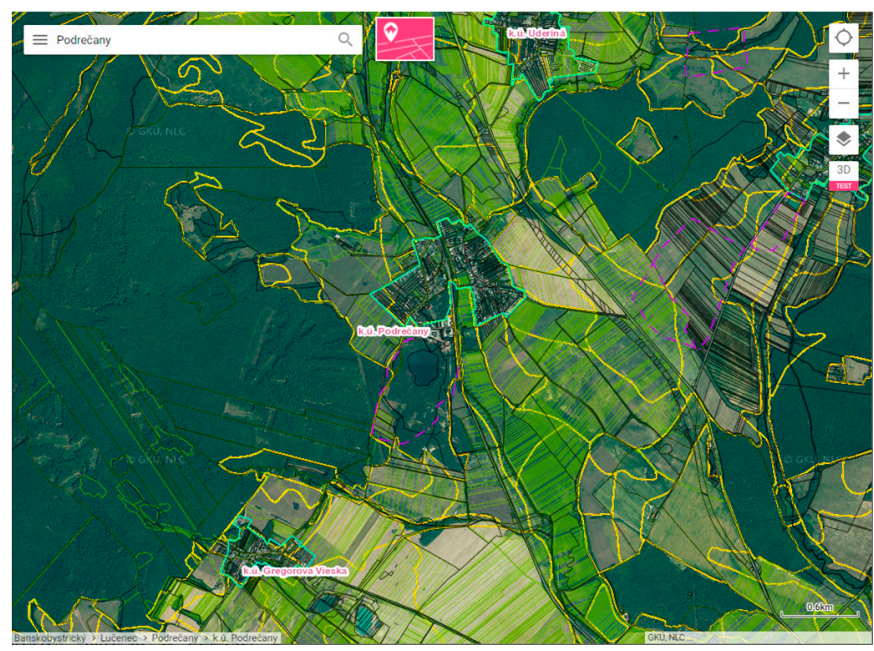

(b)

Figure 4. Map portals with EPEU layers: (a) Soil portal (Source: https:/ /portal.vupop.sk/portal/apps/webappviewer / index.html?id=1b9830b956ac411e9789aac54effa744, accessed on 21 September 2021); (b) Geoportal ZBGIS (Source: https: / / zbgis.skgeodesy.sk/mkzbgis/sk/kataster?bm=orto\&z=14\&c=19.616018,48.400452\&sc=n\#, accessed on 5 September 2021).

Data from the European Union's Copernicus Land Monitoring Service (https:/ /land. copernicus.eu/pan-european/corine-land-cover, accessed on 20 September 2021) were used to capture changes in the landscape structure of the surveyed site. Data on land cover and its changes were obtained for the period from 1990 to 2018.

\subsection{Methodology}

The methodology for processing the input data, with the resulting analyses, is shown in Figure 5.

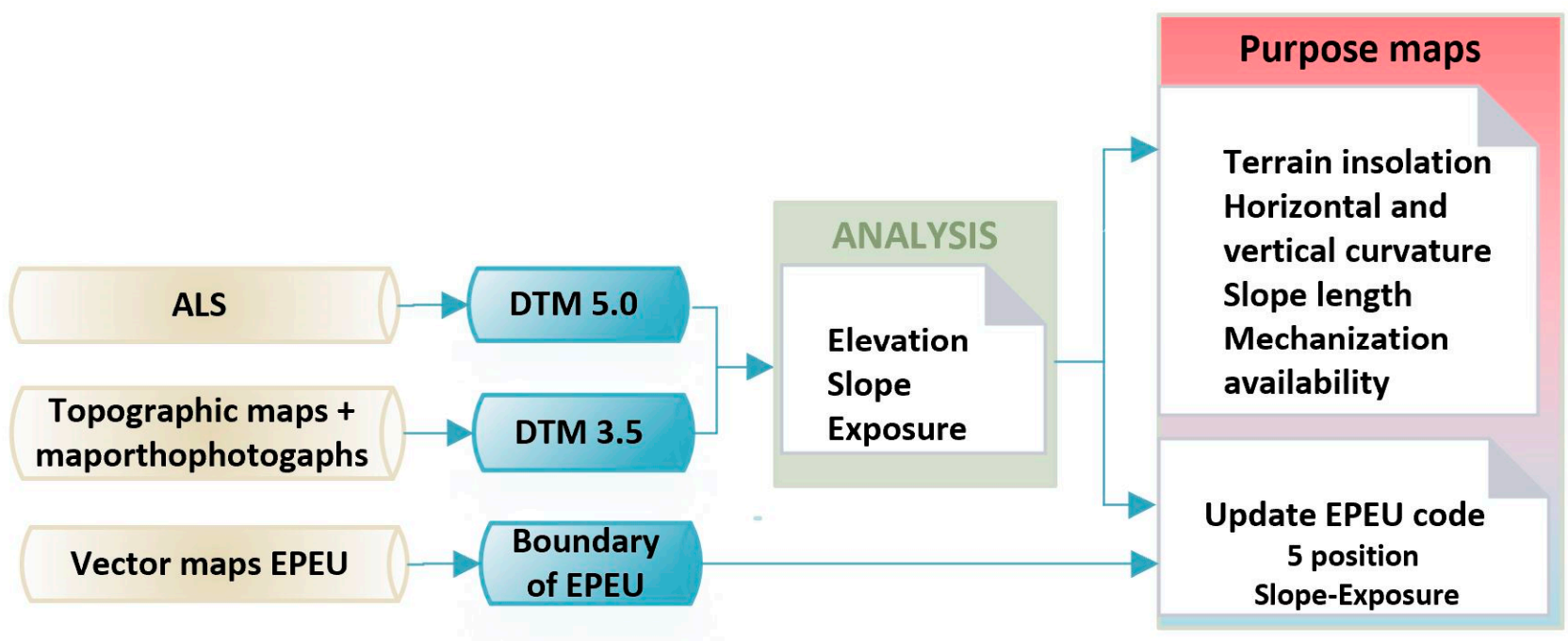

Figure 5. Flowchart of the methodology used.

As the input data were in different coordinate systems, it was necessary to transform them into a single coordinate system, namely, D-UTCN (EPSG: 5514) and the Baltic vertical reference frame after adjustment (EPSG: 8357) altitude system.

Qualitative requirements are given for topography and elevation mapping in landscaping projects, where ALS and orthophotomosaic data are available:

- For orthophotomosaic, a minimum resolution of $0.25 \times 0.25 \mathrm{~m}$ and mean position error of $\leq 0.50 \mathrm{~m}$, and 
- for DTR, a minimum resolution of $1 \times 1 \mathrm{~m}$ and a mean height error of $\leq 0.25 \mathrm{~m}$.

Details on the accuracy of the input data are given in the previous Section 2.3. The input data were used to meet the required quality parameters.

In the territory where the ALS took place and the DTM was created, we were obliged to use this data. As progress in ALS work is slow (an overview of localities can be found at www.geoportal.sk/en/zbgis/als-dtm.html, accessed on 25 September 2021), it is recommended to implement hypsography data from other sources, e.g., DTM 3.5. For our processing, DTM 3.5 data were resampled to a resolution level of $1 \times 1 \mathrm{~m}$.

The accuracy of EPEU breakpoints taken from the real estate cadastre can be classified in terms of the accuracy characteristics of the determination of mxy coordinates, according to which the EPEU breakpoint can be classified into the accuracy class-mxy without distinction.

Current legislation and technical regulations do not stipulate the required accuracy of the breaking points for EPEU boundaries. Based on the input data we used, it is possible to determine the accuracy class in a range $\mathrm{mxy}$ from 0.10 to $0.26 \mathrm{~m}$ for the future update of the EPEU breaking points. Accuracy was also affected by the results of the soil survey and the accuracy of boundaries in forest maps.

Slope and exposure are among the most basic morphometric characteristics of terrain relief. The values of the rasters as a result of analyses Slope and Aspect in ArcGIS Pro were reclassified according to the EPEU guidelines [28] (Tables 2 and 3).

Table 2. Slope codes.

\begin{tabular}{ccc}
\hline Code & Description & Slope $\left(^{\circ}\right)$ \\
\hline 0 & Flat without area water erosion events & $0-1$ \\
1 & Flat with the possibility of water erosion events & $1-3$ \\
2 & Gentle slope & $3-7$ \\
3 & Moderate slope & $7-12$ \\
4 & Strong slope & $12-17$ \\
5 & Very strong slope & $17-25$ \\
6 & Extreme slope & above 25 \\
\hline
\end{tabular}

Table 3. Exposure codes.

\begin{tabular}{cc}
\hline Code & Description \\
\hline 0 & Flat \\
1 & South expsoure \\
2 & East and west exposure \\
3 & North exposure \\
\hline
\end{tabular}

Terrain insolation represents the potential amount of received incident radiation. This may be determined based on a combination of slope and exposure relief rasters [39,40]. The obtained values were divided into seven classes.

The curvature of the relief is considered a second order morphometric parameter. Horizontal curvature is in the direction of the contour, while normal curvature is in the direction of the tangent to the contour. Curvature can be either positive or negative. Positive and negative values indicate convex and concave (hollow) shapes, respectively. The vertical curvature of the relief describes curvature in the direction of the slope curve, while normal curvature is that in the direction of the slope curve. This curvature can be either positive or negative. Curvature is a significant indicator for assessing the direction of movement, be it of water or material, down the slope. Calculations performed in ArcGIS Pro were used, based on the procedure put forward by Zevenberg and Thorne [41].

The length of slopes is defined as the length of a line from a particular point to water divide. This line represents the slope curve along which surface runoff takes place; it is the sum of the water erosion calculation in the USLE/RUSLE equation. 
Mechanization accessibility describes the slope accessibility for various agricultural mechanisms, which is influenced by slope. A purpose map illustrating this information was created by reclassifying the slope map into three classes according to the categories in Table 4.

Table 4. Mechanization accessibility classes.

\begin{tabular}{ccc}
\hline Class & Slope $\left(^{\circ}\right)$ & Description \\
\hline M I & $0-8$ & All standard mechanisms \\
M II & $8-10$ & Lighter standard mechanisms with adjustment \\
M III & $10-15$ & Specially designed equipment \\
\hline
\end{tabular}

\section{Results and Discussion}

Information on land use and cover was used to capture and monitor the changes occurring in the landscape [42] that may have been caused by human activities. By comparing Corine land cover data for the period from 1990 to 2018 (Figure 6), changes in the spatial representation of the different land cover classes in the study area were visible.

\section{CORINE Land Cover}

\section{Code}

112 Discontinuous urban fabric

131 Mineral extraction sites

211 Non-irrigated arable land

231 Pastures

243 Land principally occupied by agriculture, with significant areas of natural vegetation

311 Broad-leaved forest

324 Transitional woodland-shrub

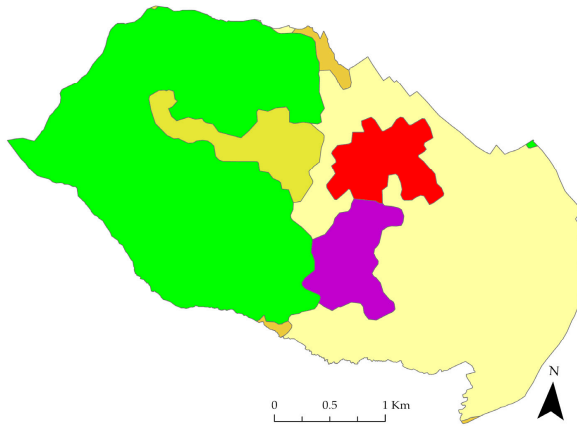

1990

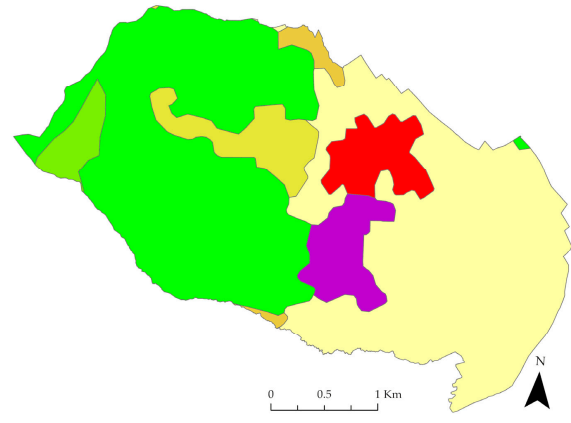

2006

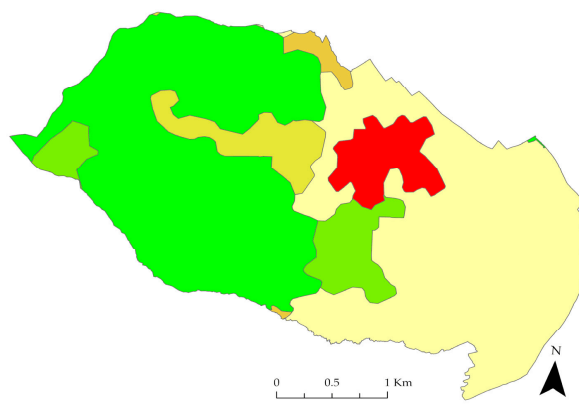

2012

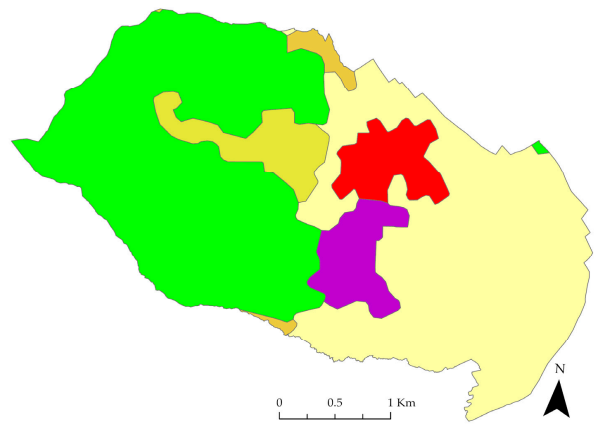

2000

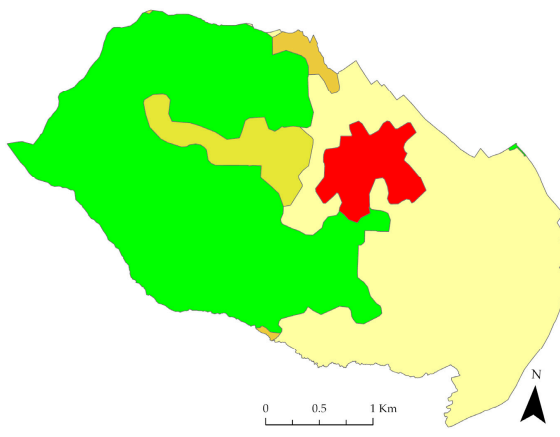

2018

Figure 6. Corine Land Cover for the selected time period.

Details of the recorded changes are given in Table 5. Between 1990 and 2006, a Mineral Extraction Sites (131) class was identified in the area. In 2012, the area was classified as transitional woodland-shrub (324), while in the next reporting period in 2018, it merged with the broad-leaved forest layer (311). Therefore, direct encroachment on the landscape due to human activity was visible at the site. 
Table 5. Representation of each CLC class for the selected period.

\begin{tabular}{cccccc}
\hline CLC Code & 1990 Area (ha) & 2000 Area (ha) & 2006 Area (ha) & 2012 Area (ha) & 2018 Area (ha) \\
\hline 112 & 57.204 & 56.629 & 56.629 & 60.133 & 57.593 \\
131 & 59.976 & 58.475 & 58.475 & & \\
211 & 470.734 & 470.893 & 471.063 & 472.909 & 475.449 \\
231 & 61.075 & 61.316 & 61.330 & 56.932 & 59.132 \\
243 & 11.332 & 15.919 & 15.926 & 14.339 & 14.431 \\
311 & 500.155 & 497.245 & 466.823 & 481.034 & 553.873 \\
324 & & & 30.232 & 75.130 & \\
\hline
\end{tabular}

In the past in the cadastre unit of Podrečany, magnesite was mined on the surface, before gradually transitioning to underground operations. The magnesite deposit was discovered in 1952, and mining started in 1956. A historical orthophotomap from 1950 (Figure 7a) shows the area with agricultural land prior to starting mining. Magnesite mining ceased in the early 1990s. The condition of the landscape after mining had ceased is shown in Figure $7 \mathrm{~b}$. There is a dump of waste mining material and a flooded mining pit. The dump has become overgrown with vegetation, which is also visible on the orthophotos (Figure $7 b$ ).

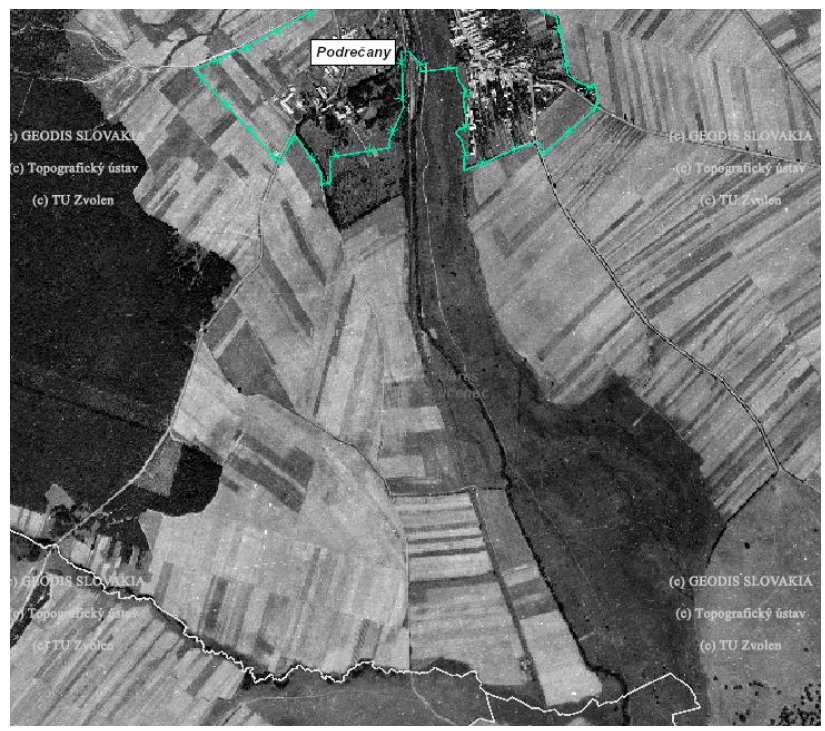

(a)

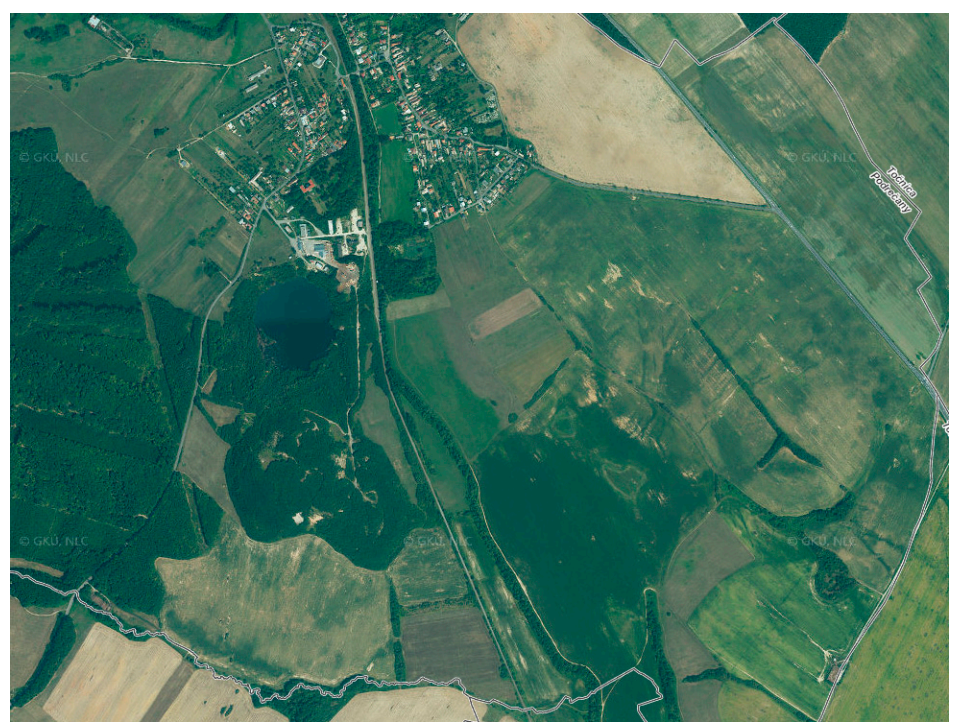

(b)

Figure 7. Changes in land use (a) 1950 (Source: mapy.tuzvo.sk/HOFM/, accessed on 29 September 2021); (b) 2018 (Source: www.geoportal.sk, accessed on 27 September 2021).

The character of the landscape has changed from the time it was used for agricultural purposes. Although mining in the area has ceased, signs of the mining activity remain, constituting an environmental burden for part of the area. The mining area has been closed, and only the defined protected area remains.

The extent of changes to the terrain due to mineral extraction is documented, and may be seen by comparing digital terrain models from different time periods. The DTM 1957 model was created on the basis of a topographic map at a scale of 1:10,000 from the period 1957-1971. The DTM 5.0 model was used for comparison. The height differences, shown in Figure 8 , are $+41.4 \mathrm{~m}$ and $-40.5 \mathrm{~m}$. However, most of the territory remained relatively unchanged. Changes are most visible in the area where the extraction of minerals took place. There is also a dump in the study area, which is mainly made up of tailings. 


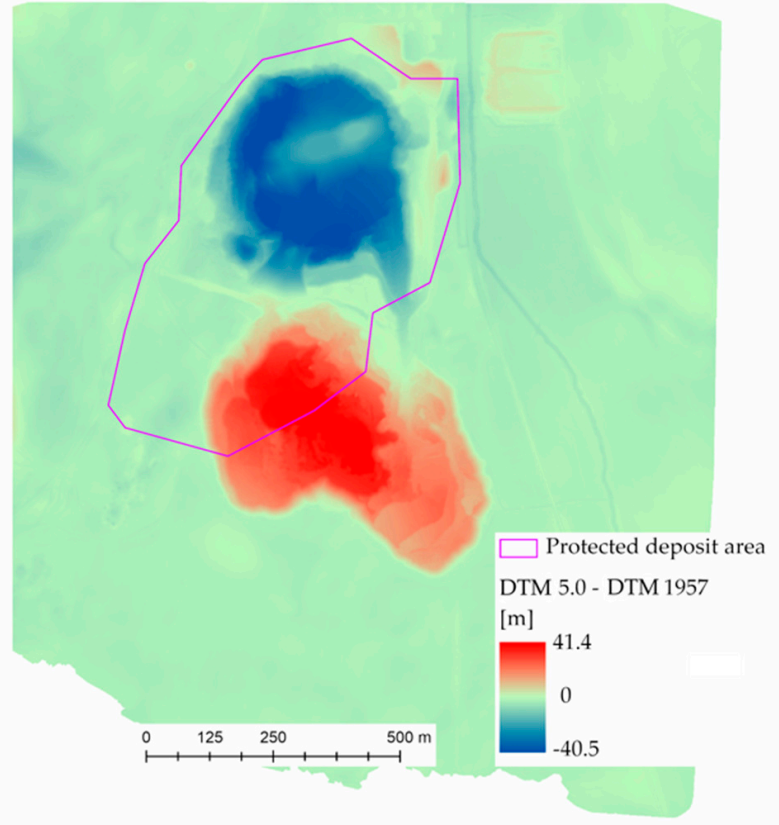

(a)

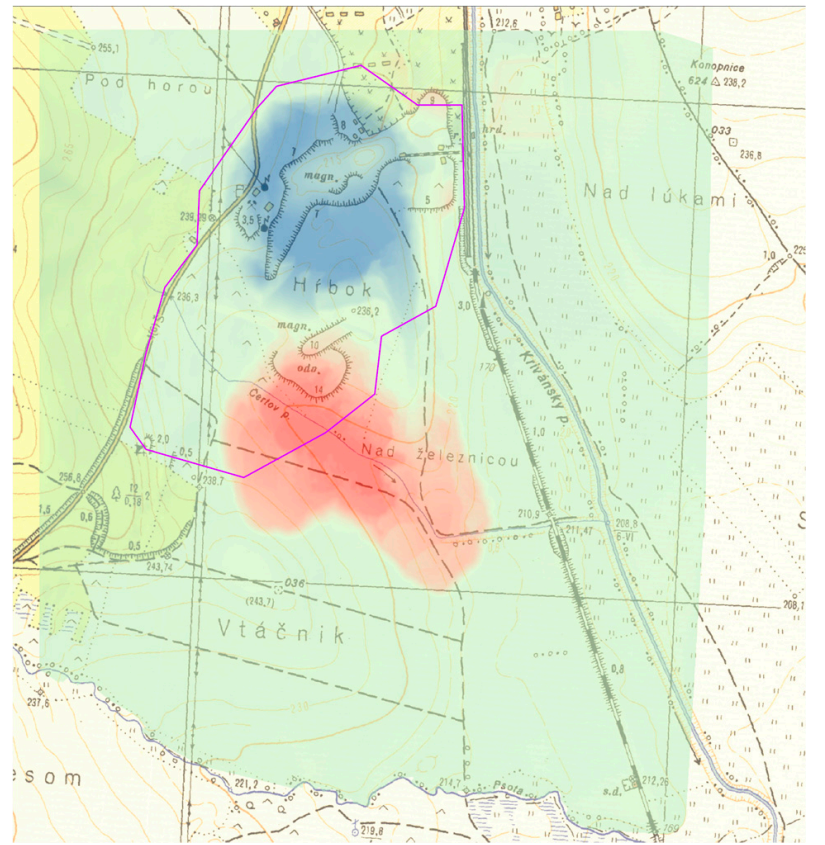

(b)

Figure 8. Elevation changes in the deposit area: (a) comparison of DTMs for the years 1957 and 2019; (b) topographic map from 1957 (Source: https: / / geoportal.gov.sk/sk/map?b=19.6012652,48.406453, accessed on 23 September 2021).

Due to the time which has elapsed since the end of mining activities in the investigated area, the heap has become naturally afforested. Figure 9 shows the terrain profile of the heap based on LiDAR data, where the terrain is shown in brown and high vegetation is shown in light green. By comparing the generated DEM and DSM from the LiDAR data, the height of the trees was estimated to be approximately $9 \mathrm{~m}$.

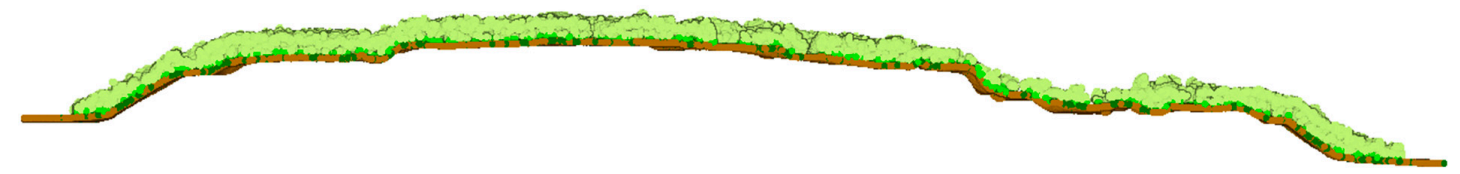

Figure 9. Terrain profile of the heap created based on LiDAR data.

Land consolidation has not yet taken place at the study site, and was not even planned for this year (2021). Given the number of cadastral areas in Slovakia (3559) and the number of completed complex land improvements (431) [43], it is necessary to use available data sources to create elevation and purpose maps and to capture changes in land use. In cases where ALS data are available (as well as the DTM created based thereon), while maintaining the required accuracy parameters, the model can serve as a basis for updating EPEU maps and creating new purpose maps. Direct alignment of the elevation in the field was carried out only in cases involving changes in the terrain that may have occurred since the creation of the DTM, and only in identified cases (i.e., following changes in the landscape due to construction activities, soil erosion).

Two models are available in the examined locality, namely DTM 3.5 and DTM 5.0. The DTM 3.5 model was resampled to a resolution of $1 \times 1 \mathrm{~m}$ by the Nearest Neighbor method. A comparison of the two models is shown in Figure 10. It was surprising to find significant height differences in the model ranges, reaching values of $-49.9 \mathrm{~m}$ to $19.8 \mathrm{~m}$. The maximum negative values were in the locality where the extraction of mineral resources had taken place and a mining pit had been created. The DTM 3.5 model, created by combining contours and photogrammetric images, did not capture these changes, and it is limited in terms of its resolution. The expected differences were in the wooded and 
hilly terrain, where the actual course of the terrain could not be accurately captured by the methods used by creation DTM 3.5.

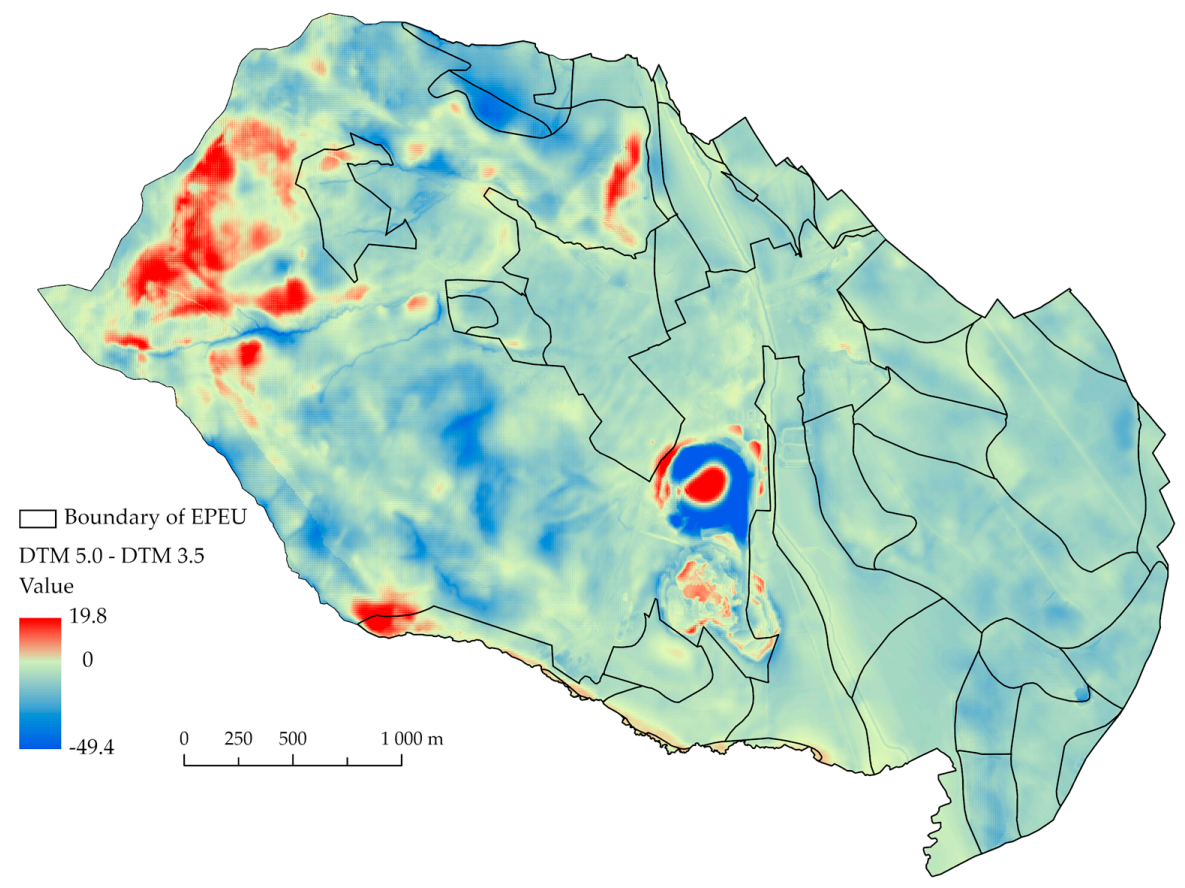

Figure 10. Comparison of height differences DTM 3.5 and 5.0.

Based on this comparison, the DTM 5.0 model is suitable for creating purpose-built maps based on elevation. The following selected maps (Figure 11), in addition to being useful in landscaping projects, could serve as a basis for calculating soil erosion, in road designs, for assessments of local territorial systems of ecological stability and for defining general principles of functional land use.

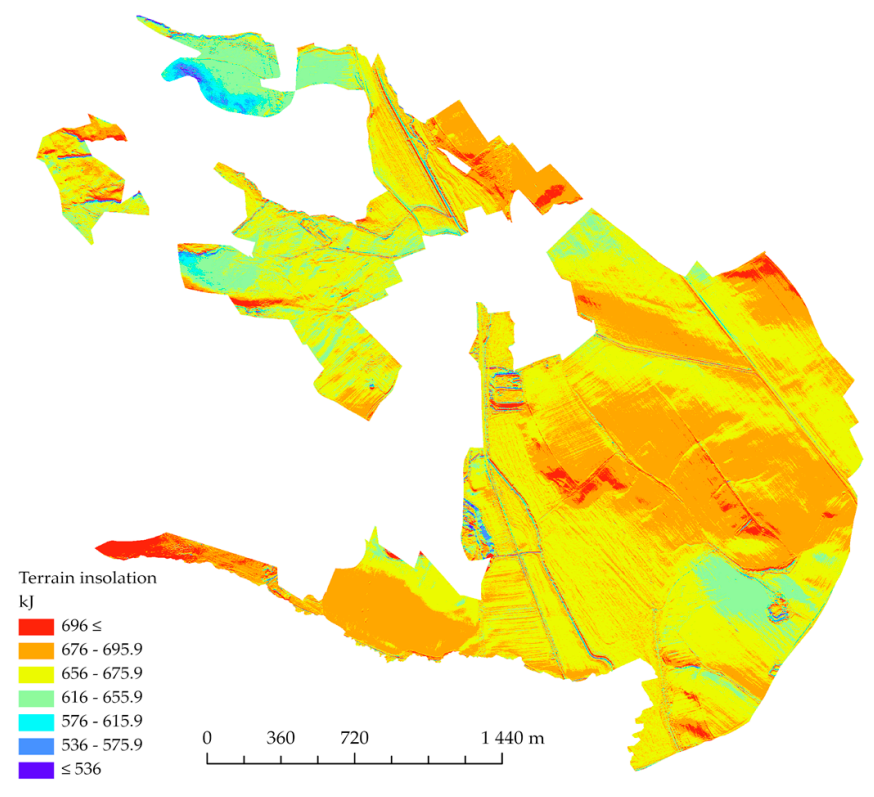

(a)

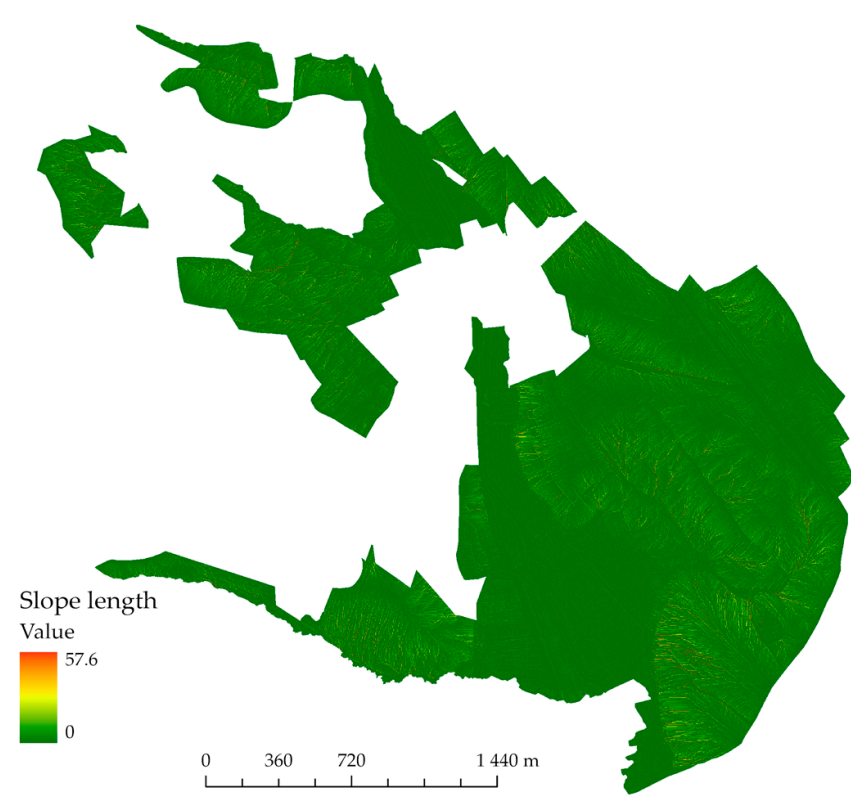

(b)

Figure 11. Cont. 


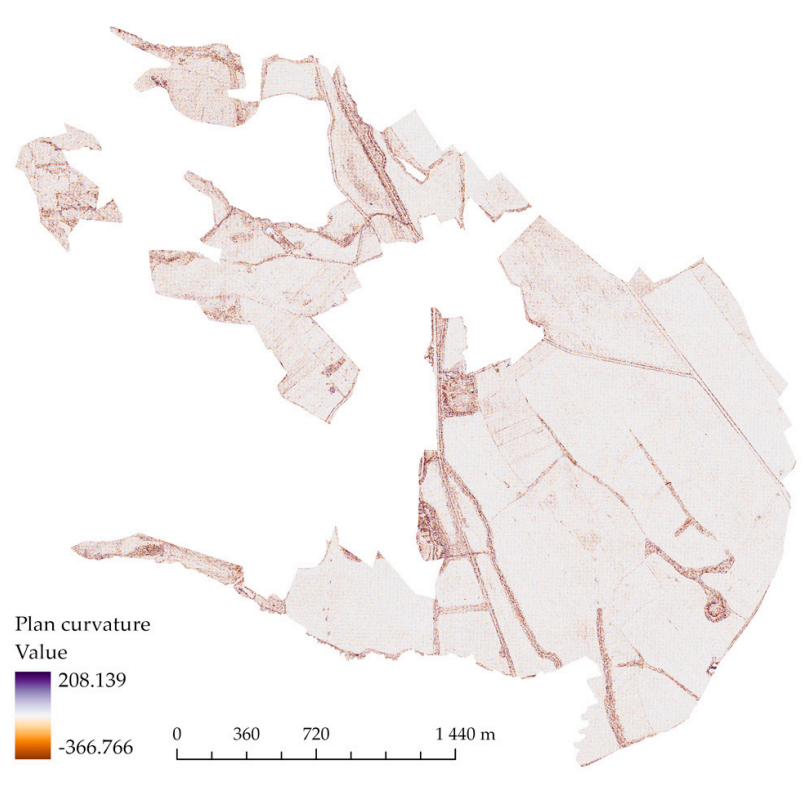

(c)

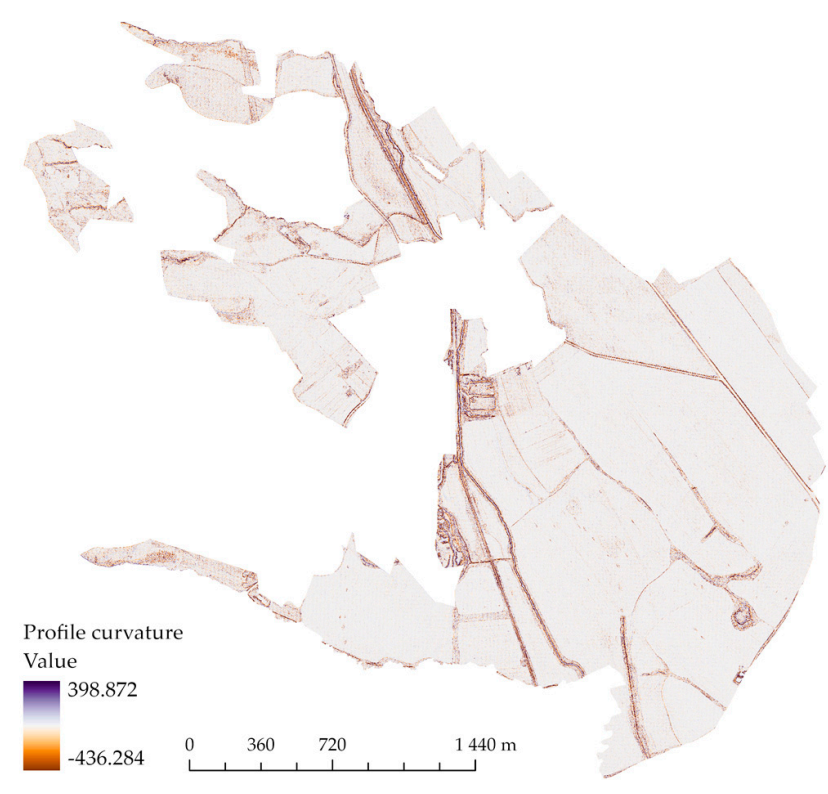

(d)

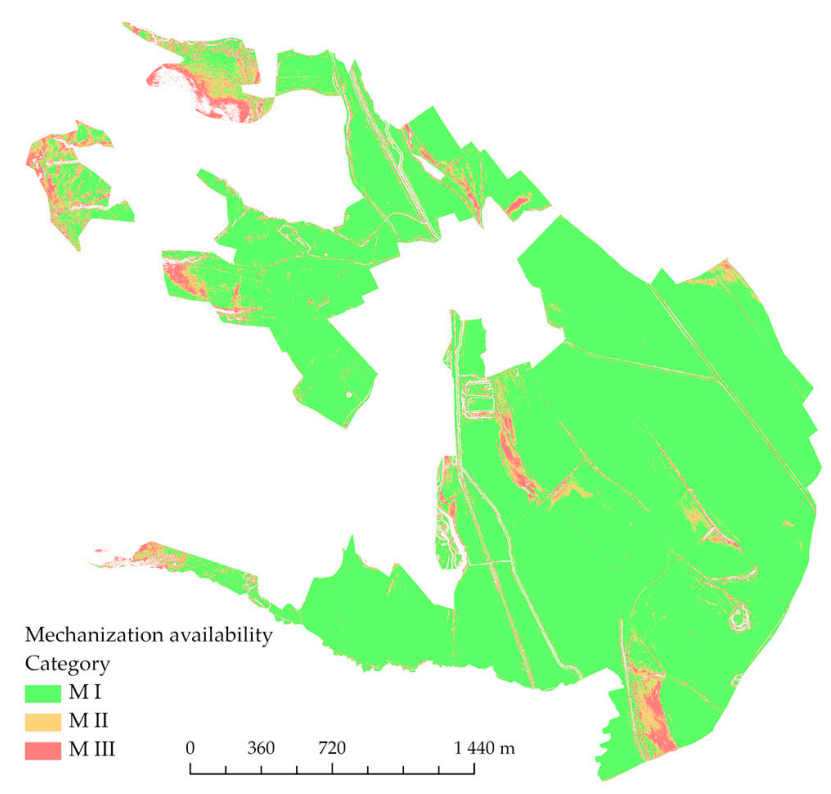

(e)

Figure 11. Purpose maps in land consolidation (a) terrain insolation; (b) Slope length; (c) Plan curvature; (d) Profile curvature; (e) Mechanization availability.

The EPEU represents a homogeneous area and it is the essential for the production of the land valuation map. For this reason, it is necessary to pay particular attention to the quality of the data in terms of their timeliness or accuracy. In the time period since the legal creation of the areas, changes in the landscape may have occurred due to both natural phenomena and anthropogenic activities.

There are a total of 41 (including 26 sites with different codes) EPEUs in the study area. The total area of the cadastral unit with defined pedologic-ecological units is 715.84 ha, representing $61.68 \%$ of the total area of the unit. Their representation and number of occurrences are shown in Figure 12. The largest area, i.e., 119.3 ha, comprises the EPEU with code 0411002 , while the smallest area, making up just 1.5 ha, was designated as 0560442. 


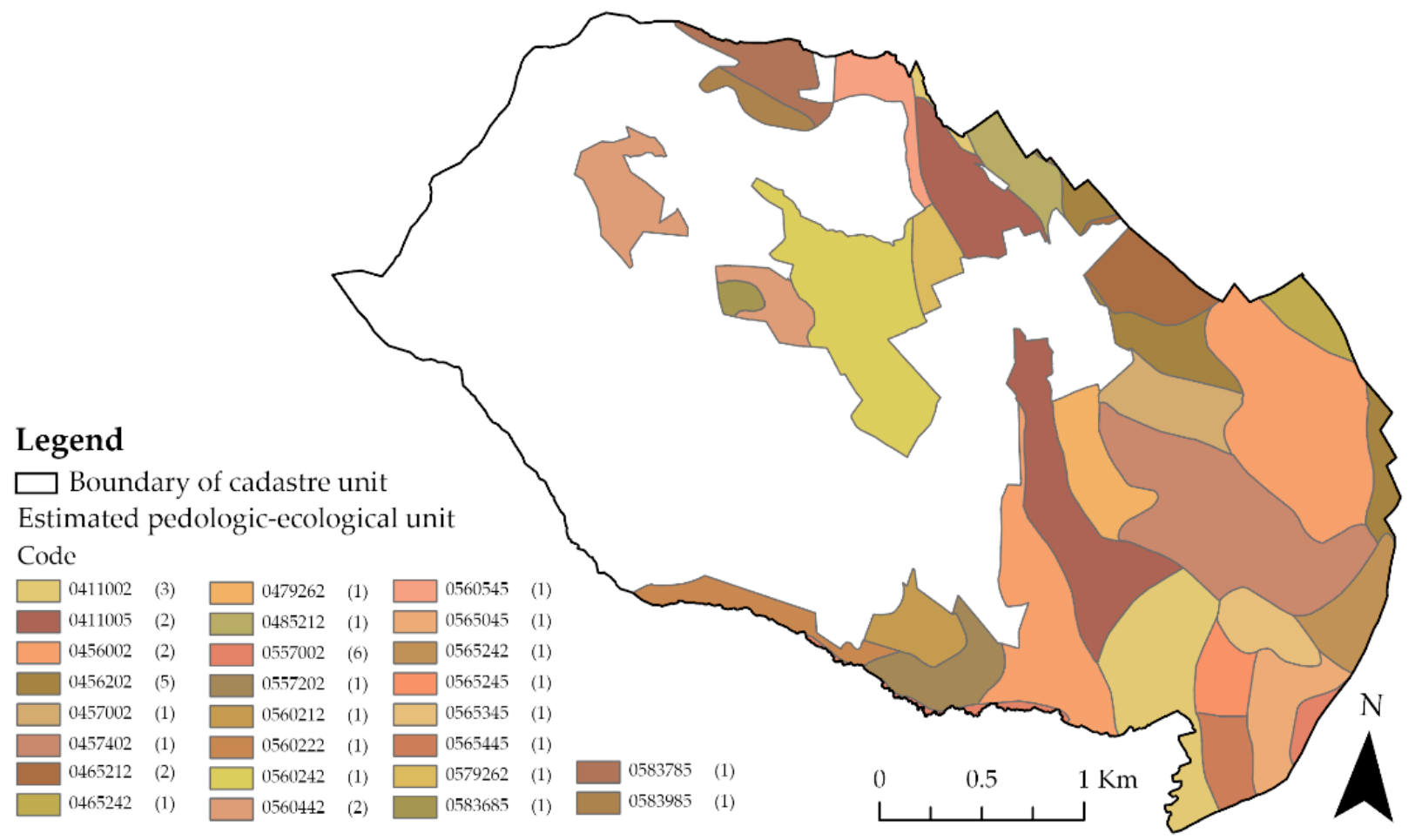

Figure 12. Estimated pedologic-ecological units in the cadastral unit Podrečany.

The terrain characteristics are also an important part of the EPEU coding system, namely, the slope gradient and the orientation of the slopes relative to the cardinal points (compass direction), expressed by the slope and exposure code (position 5). This value is given for the entirety of each EPEU area, and is expressed as a combination of the slope and exposure code. In order to update these values, the results of purpose-built altimetric and planimetric surveys are used in accordance ongoing land consolidation projects in individual cadastral units. The Slovak Republic is currently processing data from airborne laser scanning (www.geoportal.sk/en/zbgis/als-dtm.html, accessed on 22 September 2021); it is possible to use this data source to update these two parameters (see Section 2.3 Input data). The data reconciliation solution was based on existing EPEU areas and analyses of the digital terrain model (DTM 5.0) in the selected cadastral unit.

Slope gradient is also an important parameter that is part of the seven-digit EPEU code. Figure 13a shows the slope of the terrain according to the values in the EPEU code. In the study area, the most frequently occurring code, i.e., 2, occurred a total of 18 times, representing an area of $210.96 \mathrm{ha}$. The second most prominent code was 0.1 , but with a larger area of 235.75 ha. The slope gradient created from the digital terrain model (Figure 13b) represents the current state of the terrain.

The slope code applies to the entire EPEU area. To confirm the existing code harmonization or to identify the need for updates, we used two approaches. Figure $13 \mathrm{c}$ presents the slope code assignments based on the calculated average value for each site. In this case, 21 distinct areas were identified. In the second approach, we created a histogram for each area according to the basic interval distribution; subsequently, each area was assigned the most frequently-occurring value. The results of this process are shown in Figure 13d. The values expressing the slope were different in 13 cases. 


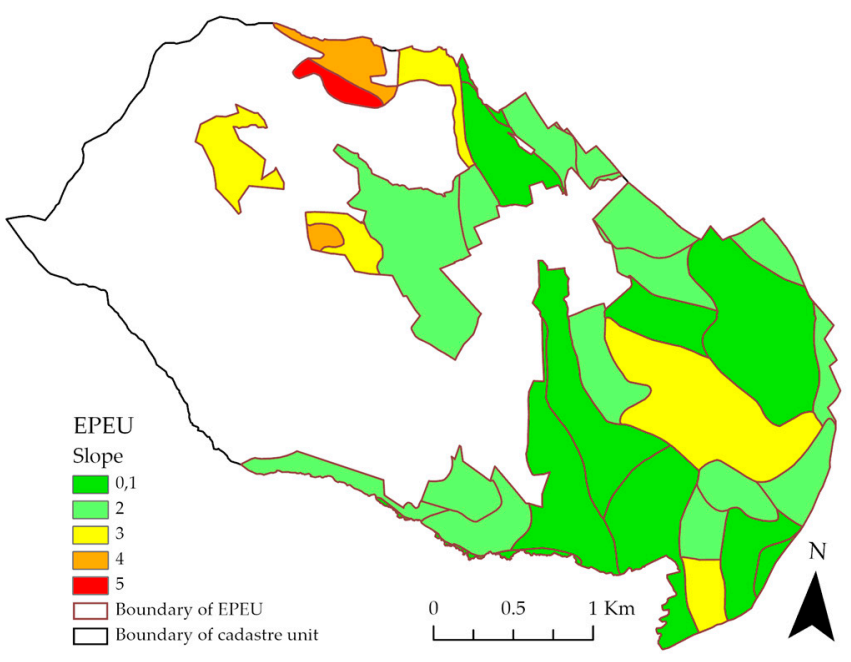

(a)

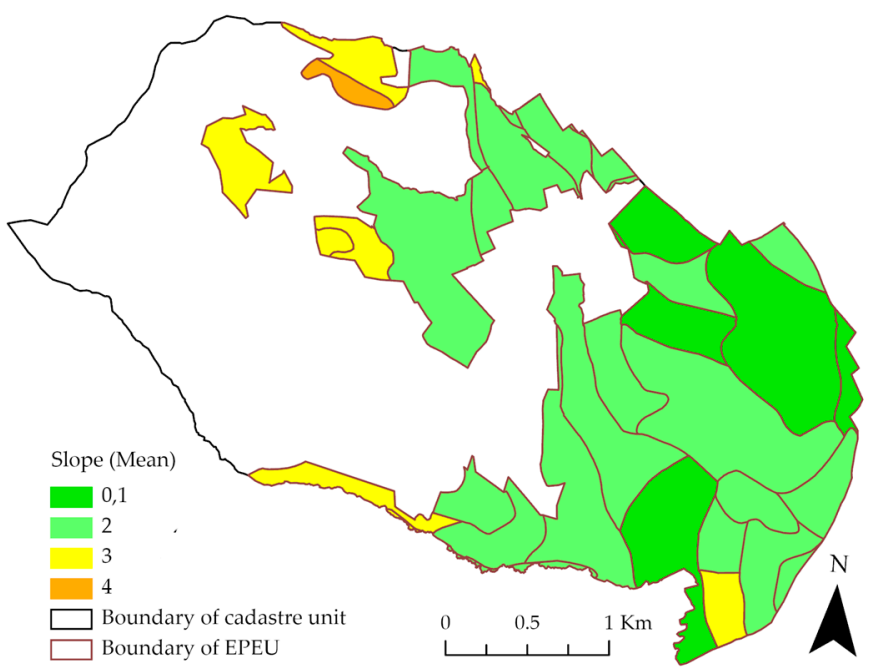

(c)

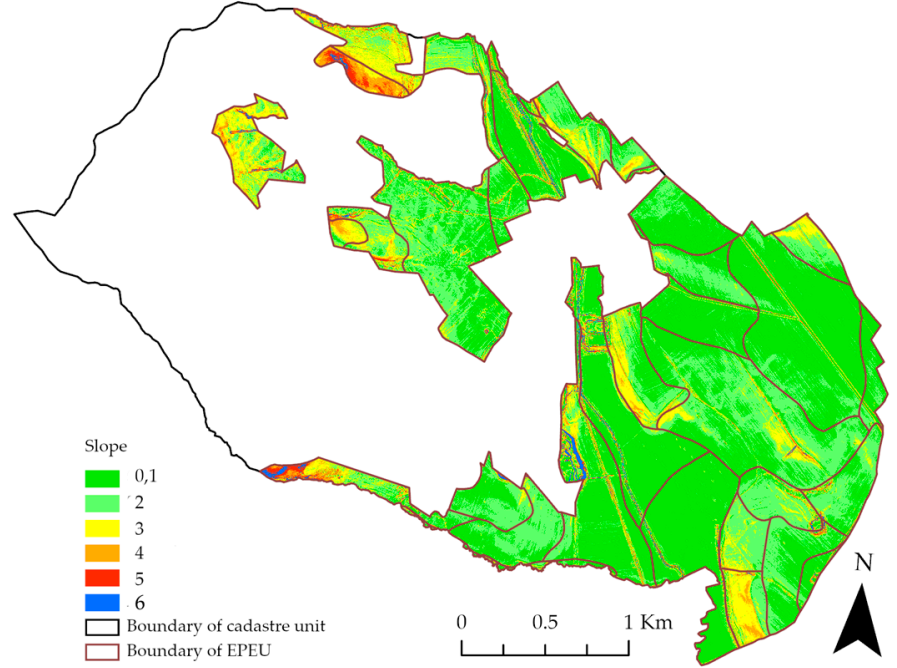

(b)

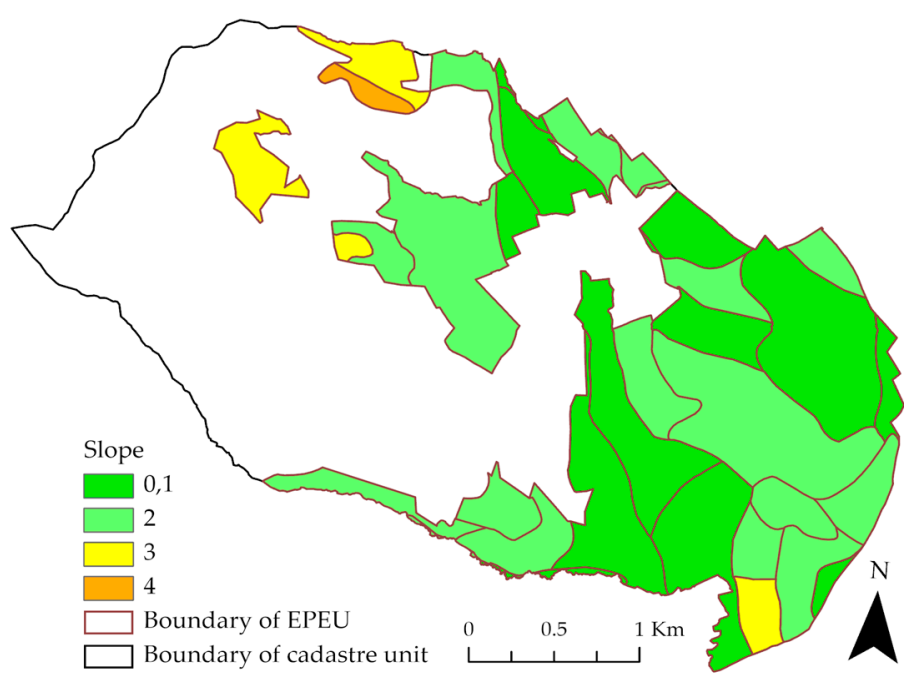

(d)

Figure 13. Slope code values assigned based on Table 2 (a) by EPEU; (b) by DTM 5.0; (c) by mean; (d) by histogram.

To compare the second parameter, we based the exposure data on the EPEU code and the exposure according to our analysis of the digital terrain model available for the area. Of the 41 EPEUs, 15 areas had the exposure parameter set to 0 (flat), representing 235.75 ha (33\%) of the total 715.84 ha EPEU area. According to [28], the data were divided into three basic classes (Figure 14a). When analyzing the DTM and using the Aspect function, it was found that only five raster cells could be categorized as "flat", representing an area of just $5 \mathrm{~m}^{2}$. For comparison, the data were equally classified (Figure $14 \mathrm{~b}$ ).

Based on our spatial aspect analysis, the most frequently occurring value was calculated for each EPEU unit (see Figure 14c). According to this value, it was possible to classify all units as south-oriented (code 1) or east- and west-oriented (code 2), according to the EPEU classification. 


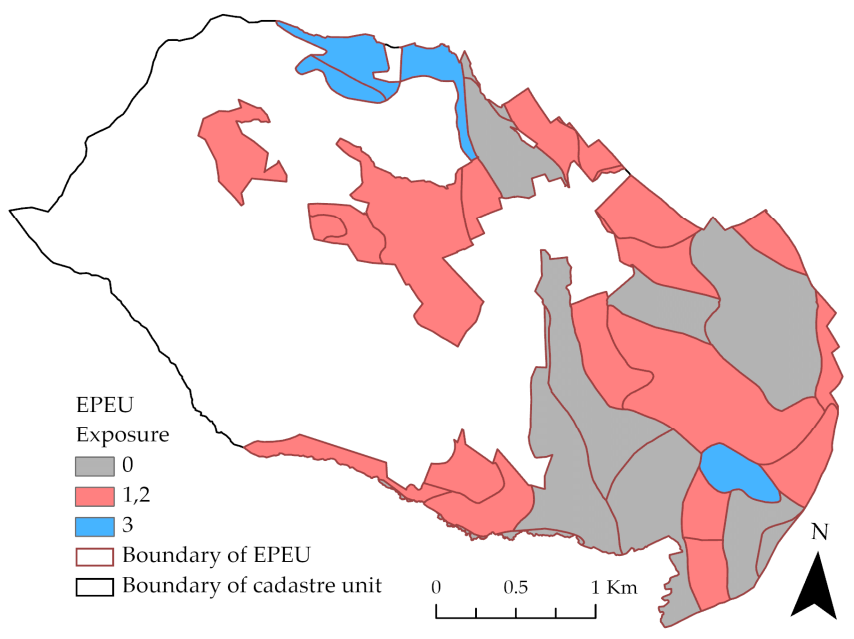

(a)

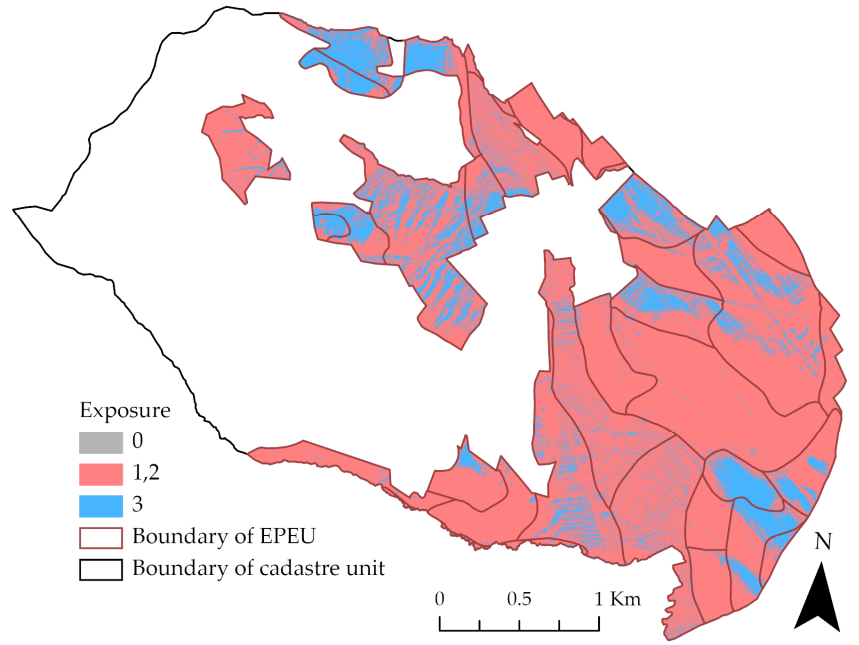

(b)

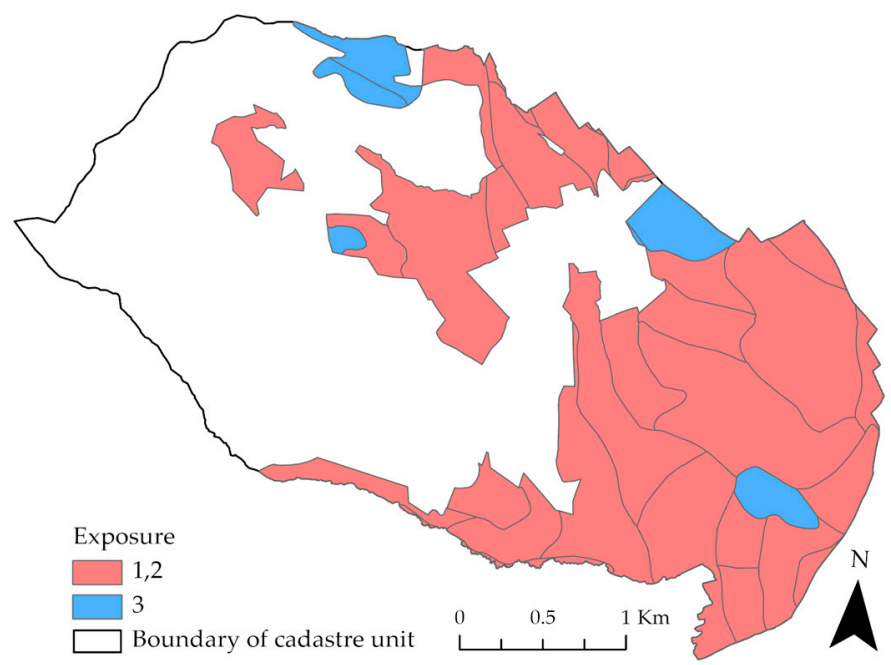

(c)

Figure 14. Exposure (a) by EPEU; (b) by DTM 5.0; (c) by histogram.

Updating EPEU areas is especially necessary for locations where changes have occurred due to human activity or natural factors. These changes include soil damage due to landscaping, changes in soil properties as a result of mining activities and subsequent reclamation, or significant surface damage caused by landslides.

Over time, the land use of the site has changed, as shown in Figure 15a. The red line shows the areas from the Land Parcel Identification System (LPIS) database. The database contains agricultural land boundaries in vector form with an attached table of attributes (unique code, area, crop, land use, etc.). The data also served as a basis for applications from farmers for subsidies. The yellow line shows the boundary of the EPEU area code 0560212. 


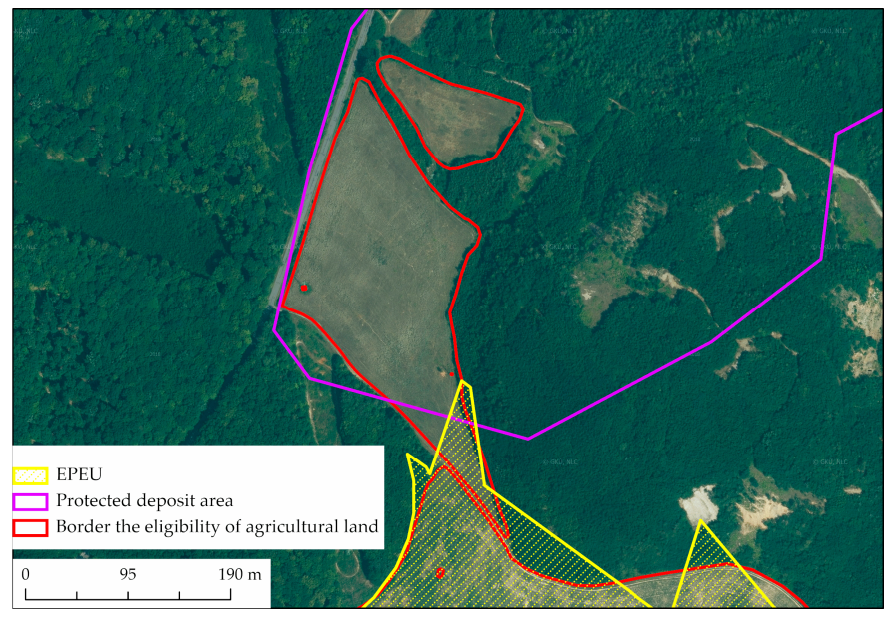

(a)

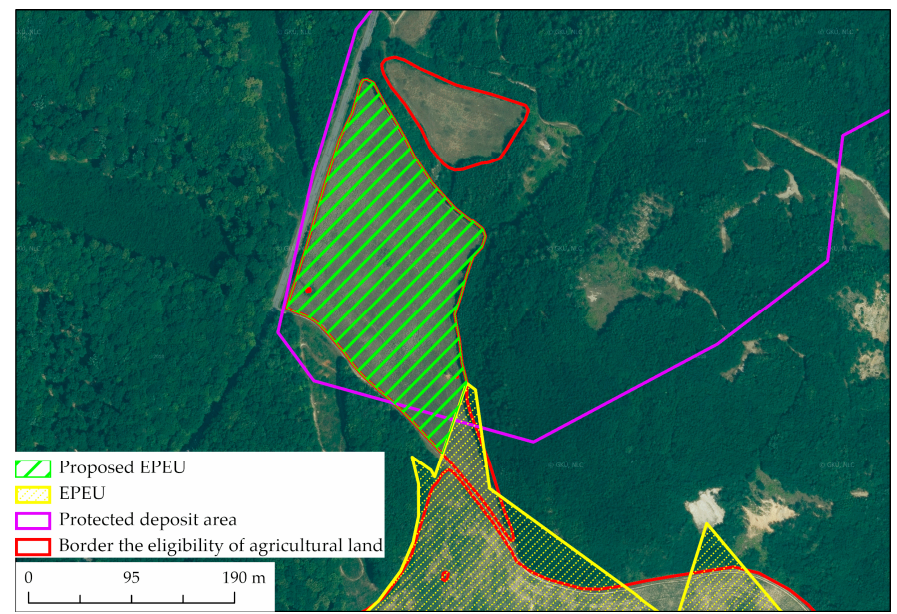

(b)

Figure 15. EPEU layers and LPIS use boundaries; (a) existing EPEU status; (b) proposed EPEU area.

The characteristics of the area according to the given EPEU code are:

05 climatic region-relatively warm, dry, basin, continental,

60 main soil unit-dystric cambisols and cambic umbrisols, acid to distinctly acid, from weathering products of crystalline rocks, medium heavy to arenic,

2 slope-gentle slope $3-7^{\circ}$ (code 2 ) and exposure-south, east and west (code 1,2),

1 stoniness-weakly skeletal soils,

2 depth-shallow soils up to $30 \mathrm{~cm}$.

Since the subject of EPEU mapping has been primarily agricultural land, and until the 1990s, mineral extraction was taking place in the area, the area that is currently beginning to be repurposed as agricultural land is not captured in the EPEU system. The vector base from the LPIS can be used to define the boundary of the proposed EPEU area. The green diagonal lines in Figure 15b show the possible alignment of the proposed 3.26 ha EPEU unit.

Due to the continuity of the areas of the existing EPEU site and the proposed site, it was possible to assign the local code 0560212. To verify the slope and exposure code (5 positions), slope and aspect analyses were performed with subsequent reclassification of the data to the required classes. From the output shown in Figure 16a, and the fact that the highest incidence of slope was within the range of $3-7^{\circ}$ (Figure 16b), code 2 for slope was assigned. Figure 16c shows that the orientation is south, east, and west, so the exposure code is 1.2. According to the process described in [28], the resulting value is 2, and it corresponds to the code value at the fifth position of the existing EPEU unit.

Updated EPEU data is recorded in different government systems; as a result, the data on EPEU areas differ in terms of their processing format and the delivery of the results in vector documents for EPEU map updates. According to different legislative regulations and the procedural processes and methodologies of state authorities, these are stored in the information system of the cadastre of real estate, databases of land departments of individual district offices, SVIS, as well as in databases of other government departments. 


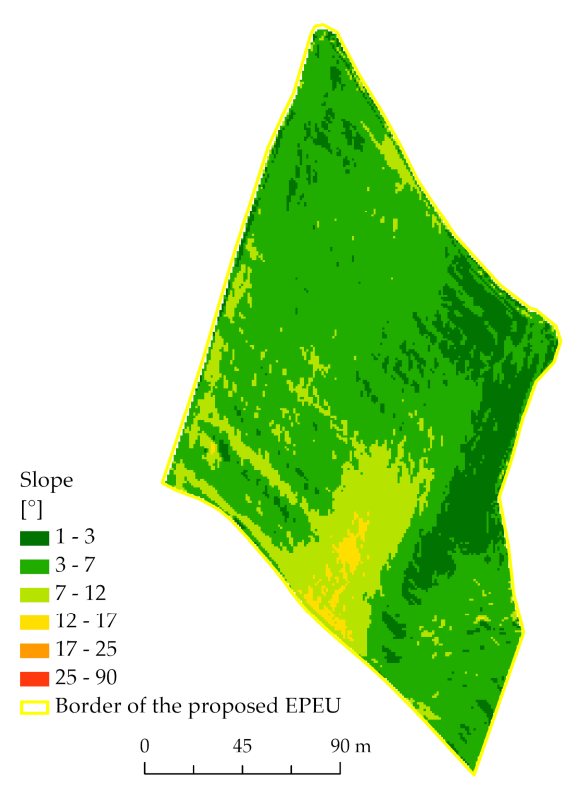

(a)

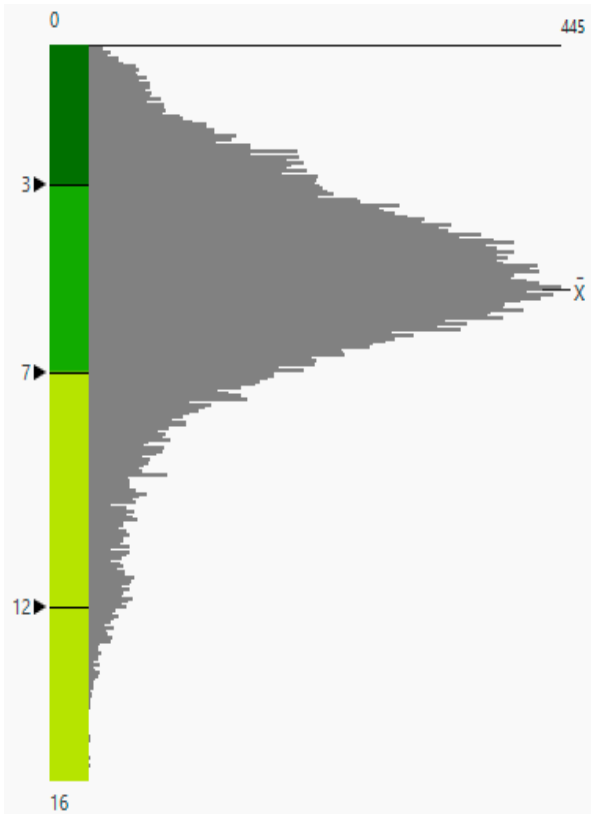

(b)

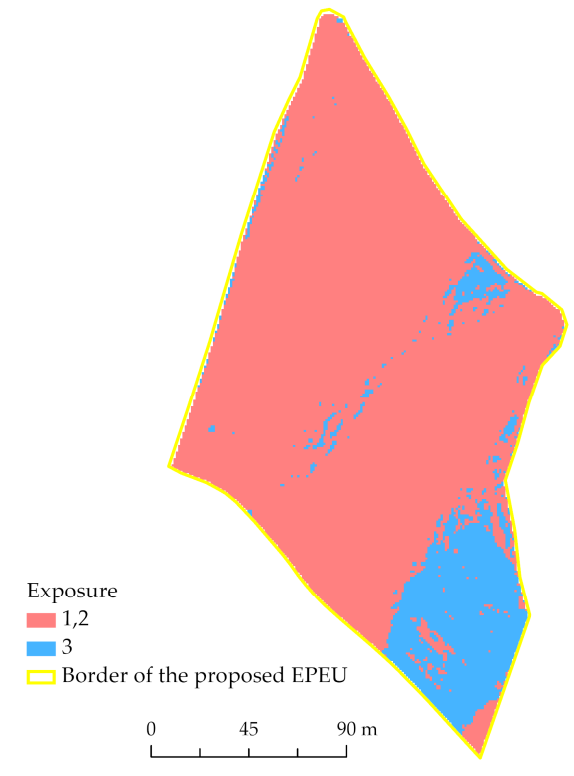

(c)

Figure 16. Verification of the EPEU code of the proposed area (a) slope analysis; (b) histogram from the slope analysis; (c) exposure analysis.

An example is the erroneous course of EPEU boundaries implemented by LC. Figure 17a shows the yellow line of the EPEU areas in the ZBGIS application (agro layers), which is available to the public. The figure on the right (Figure 17b) shows the progression of the updated EPEU boundaries after the implementation of LC from the land registry records. The EPEU data in the real estate cadastre were updated in some areas following terrestrial geodetic surveys (Global Navigation Satellite System) and field surveys.

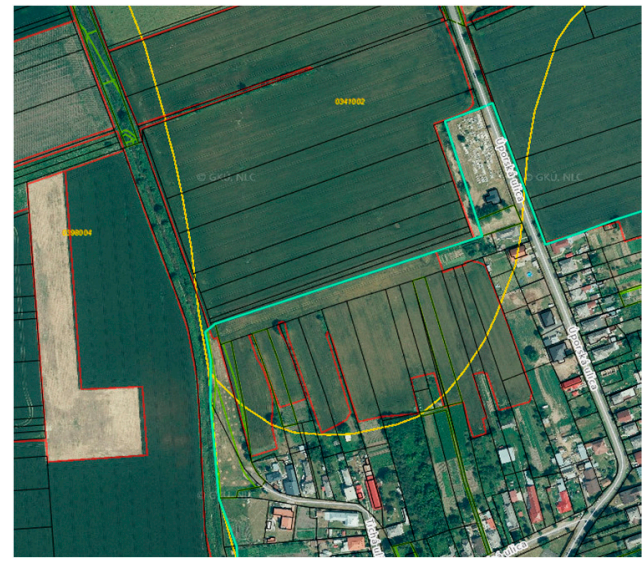

(a)

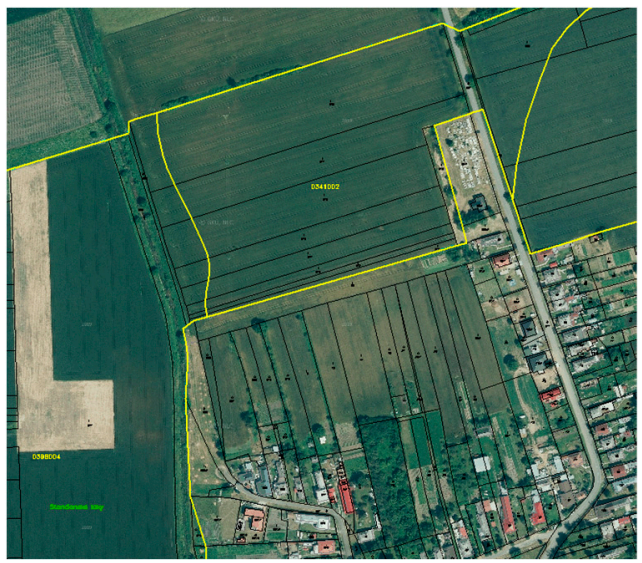

(b)

Figure 17. Illustration of differences in the registration of EPEU areas in the cadastral unit after LC registration into the real estate cadastre: (a) Agro layer of ZBGIS; (b) from the real estate cadastre.

It can be stated that, with regard to the digitized EPEU boundaries in the 1980s, which were determined without a geodetic basis, the update at the initial stage of the LC is a reliable basis for the positional determination of the break points of the EPEU boundaries outside the built-up area of the municipalities. 


\section{Conclusions}

The implementation of past and current EU strategic policies on land protection and use has also been reflected in changes to legislation in many countries, which ultimately seek to create a set of accessible and harmonized data that can be used over time in terms of land sustainability. On one hand, there is the influence of European policy. On the other hand, there is already existing and only partially amended legislation and insufficiently interoperable functioning systems based on building on historically established ways of recording information. These often cannot be considered trustworthy. Importance must be given to effective land conservation strategies, new technologies in the creation of high-quality digital models that will bring new knowledge and information to landscape processes located outside the built-up area with agriculturally usable land types.

Maintaining up-to-date data and characteristics in the EPEU system is an essential condition for the use of soil valuation. The results of soil valuation are a non-negligible factor of the economic aspect in the evaluation and valuation of soils. The determination of the official price of land, the rental value of land, and the levy for land deprivation are all important and relevant parts of state policy in connection with land protection and sustainable agriculture.

In Slovakia, there is a clear lack of interministerial and supraministerial coordination regarding individual processes related to agricultural land. EPEU data describing the state of the landscape (e.g., contours-DTM, boundaries of agricultural as well as nonagricultural areas, built-up areas, water areas) could be updated using data from airborne laser scanning and orthophotomosaics. The boundaries of agricultural areas are also recorded in the LPIS, in which GSAA data have been incorporated. GSAA (www.gsaa.sk/, accessed on 10 September 2021) contains up-to-date crop and boundary data, produced following geodetic measurements taken on the ground.

The lack of interoperability of land information systems has resulted in a lack of integration of imaging and interpretation. This creates an opaque situation in terms of evaluations of agricultural land for end-users, be they landowners or tenants, between the map outputs of the actual positioning of EPEU boundaries and more correct approaches. This is indicative of inefficient use of already depleted funds, in the form of different EPEU registration in the information system of cadastre of real estate and the ISVS. Updating the boundaries and elements in the EPEU database is the subject of the methodology, which presents a proposed solution in the form of using existing, freely available data to accelerate the amelioration of the currently unused approach for processing existing EPEU data, given that the implementation of LC is proceeding in the SR at a slow pace (out of a total number of 3569 cadastral units, 431 LCs have been carried out).

The role of the state should be to respond more flexibly to the needs of society in the 21st century, focusing on new and modern technologies in the form of better procedures and professionally trained personnel. An example of this can be found regarding the digitization of a comprehensive soil survey as part of the development of a soil quality IS in the Czech Republic. In this process, the INSPIRE Directive (standardization) is being implemented, using the KPP database from the 1980s and the World Reference Base for Soil Resources WRB by FAO (www.fao.org/3/i3794en/I3794en.pdf, accessed on 16 September 2021). The aim should be to make high quality and reliable soil data available from the European Soil Data Centre (ESDAC) system.

Author Contributions: Conceptualization, Z.K., S.K. (Stefan Kuzevic), S.K. (Samer Khouri) and D.B.; methodology Z.K. and D.B.; software, Z.K.; validation, Z.K. and S.K. (Stefan Kuzevic); formal analysis, Z.K., S.K. (Stefan Kuzevic) and D.B.; investigation, D.B.; resources Z.K.; data curation, Z.K., S.K. (Stefan Kuzevic) and D.B.; writing—original draft preparation, Z.K., S.K. (Stefan Kuzevic), S.K. (Samer Khouri) and D.B.; writing-review and editing, S.K. (Stefan Kuzevic); visualization, Z.K., S.K. (Stefan Kuzevic), S.K. (Samer Khouri) and D.B.; supervision, S.K. (Stefan Kuzevic). All authors have read and agreed to the published version of the manuscript. 
Funding: This research was funded by Scientific grant agency of Ministry of Education, Science, Research and sport of the Slovak Republic, grant number VEGA 1/0797/20.

Institutional Review Board Statement: Not applicable.

Informed Consent Statement: Not applicable.

Data Availability Statement: The data used in this study are publicly through Geoportal https: //www.geoportal.sk/en/, web site https://land.copernicus.eu/ and Soil portal https://portal. vupop.sk/portal/apps/webappviewer/index.html?id=d89cff7c70424117ae01ddba7499d3ad.

Acknowledgments: Thanks to data owner Geodesy, Cartography and Cadastre Authority of the Slovak Republic (ÚGKK SR) and data provider Geodetic and Cartographic Institute Bratislava for providing orthophotomosaics, and DTM 5.0 and DTM 3.5. Thanks to the landcover data produced under the CORINE program.

Conflicts of Interest: The authors declare no conflict of interest.

\section{References}

1. Communication from the Commission to the Council, the European Parliament, the European Economic and Social Committee and the Committee of the Regions-Thematic Strategy for Soil Protection (SEC(2006)620) (SEC(2006)1165). Available online: https: / / eur-lex.europa.eu/legal-content/EN/TXT/?uri=celex\%3A52006DC0231 (accessed on 28 June 2021).

2. Transforming Our World: The 2030 Agenda for Sustainable Development. Available online: https://sustainabledevelopment.un. org/post2015/transformingourworld (accessed on 11 June 2021).

3. Communication from the Commission to the European Parliament, the European Council, the Council, the European Economic and Social Committee and the Committee of the Regions the European Green Deal COM/2019/640 Final. Available online: https: / / eur-lex.europa.eu/legal-content/EN/TXT/?uri=COM\%3A2019\%3A640\%3AFIN (accessed on 28 June 2021).

4. Recovery and Resilience Facility Next Generation EU. Available online: https:/ / ec.europa.eu/info/business-economy-euro/ recovery-coronavirus / recovery-and-resilience-facility_en\#the-facility-and-nextgenerationeu (accessed on 24 June 2021).

5. The Recovery and Resilience Plan for Slovakia. Available online: https://www.planobnovy.sk/files/dokumenty/kompletnyplan_obnovy.pdf (accessed on 24 June 2021).

6. Pagáč Mokrá, A.; Pagáč, J.; Muchová, Z.; Petrovič, F. Analysis of ownership data from consolidated land threatened by water erosion in the Vlára basin, Slovakia. Sustainability 2021, 13, 51. [CrossRef]

7. Janus, J.; Ertunç, E. Differences in the effectiveness of land consolidation projects in various countries and their causes: Examples of Poland and Turkey. Land Use Policy 2021, 108, 105542. [CrossRef]

8. Van Dijk, T. Wanted: Alternatives for Program-Driven Land Consolidation. Symposium on Modern Land Consolidation (2004) Volvic (Clermont-Ferrand). Available online: https:/ / www.fig.net/resources/proceedings/2004/france_2004_comm7/papers_ symp/ts_05_vandijk.pdf (accessed on 20 June 2021).

9. Zákon Slovenskej Národnej Rady č. 330/1991 Zb. O Pozemkových Úpravách, Usporiadaní Pozemkového Vlastníctva, Pozemkových Úradoch, Pozemkovom Fonde a o Pozemkových Spoločenstvách v Znení Neskorších Predpisov. Available online: https: / / www.slov-lex.sk/pravne-predpisy/SK/ZZ/1991/330/ (accessed on 23 June 2021).

10. Owens, P.N. Soil erosion and sediment dynamics in the Anthropocene: A review of human impacts during a period of rapid global environmental change. J. Soils Sediments 2020, 20, 4115-4143. [CrossRef]

11. Ashraf, M.A.; Faheem, M. Environmental toxicology and biogeochemistry of ecosystems. Environ. Sci. Pollut. Res. 2020, 27, 37173-37175. [CrossRef] [PubMed]

12. Ruggles, T.A.; Gerrath, J.A.; Ruhm, C.T.; Jefferson, A.J.; Davis, C.A.; Blackwood, C.B. Surface mines show little progress towards native species forest restoration following 35 years of passive management after initial reclamation. Land Degrad. Dev. 2021, 27, 37173-37175. [CrossRef]

13. Friedl, M.A.; McIver, D.K.; Hodges, J.C.F.; Zhang, X.Y.; Muchoney, D.; Strahler, A.H.; Woodcock, C.E.; Gopal, S.; Schneider, A.; Cooper, A.; et al. Global land cover mapping from MODIS: Algorithms and early results. Remote Sens. Environ. 2002, 83, $287-302$. [CrossRef]

14. Alam, A.; Bhat, M.S.; Maheen, M. Using Landsat satellite data for assessing the land use and land cover change in Kashmir valley. GeoJournal 2020, 85, 1529-1543. [CrossRef]

15. Jamal, S.; Ahmad, W.S. Assessing land use land cover dynamics of wetland ecosystems using Landsat satellite data. SN Appl. Sci. 2020, 2, 1891. [CrossRef]

16. Hansen, M.C.; Loveland, T.R. A review of large area monitoring of land cover change using Landsat data. Remote Sens. Environ. 2012, 122, 66-74. [CrossRef]

17. Zaidi, S.M.; Akbari, A.; Samah, A.A.; Kong, N.S. Landsat-5 time series analysis for land use/land cover change detection using NDVI and semi-supervised classification techniques. Pol. J. Environ. Stud. 2017, 26, 2833-2840. [CrossRef] 
18. Capolupo, A.; Monterisi, C.; Saponaro, M.; Tarantino, E. Multi-temporal analysis of land cover changes using Landsat data through Google Earth Engine platform. In Proceedings of the Eighth International Conference on Remote Sensing and Geoinformation of the Environment (RSCy2020), Paphos, Cyprus, 16-18 March 2020; p. 1152419. [CrossRef]

19. Midekisa, A.; Holl, F.; Savory, D.J.; Andrade-Pacheco, R.; Gething, P.W.; Bennett, A.; Sturrock, H.J.W. Mapping land cover change over continental Africa using Landsat and Google Earth Engine cloud computing. PLoS ONE 2017. [CrossRef]

20. Stöcker, C.; Nex, F.; Koeva, M.; Gerke, M. High-quality uav-based orthophotos for cadastral mapping: Guidance for optimal flight configurations. Remote Sens. 2020, 12, 3625. [CrossRef]

21. Pawłuszek, K.; Marczak, S.; Borkowski, A.; Tarolli, P. Multi-aspect analysis of object-oriented landslide detection based on an extended set of LiDAR-derived terrain features. ISPRS Int. J. Geo-Inf. 2019, 8, 321. [CrossRef]

22. Sugarbaker, L.J.; Carswell, W.J., Jr. The 3D Elevation Program-Precision agriculture and other farm practices. U. S. Geol. Surv. Fact Sheet 2016, 2016-3088. [CrossRef]

23. Friedl, M.A. Remote sensing of croplands. In Comprehensive Remote Sensing; 2017; Volume 1-9, pp. 78-95, ISBN 9780128032206. Available online: https://www.sciencedirect.com/science/article/pii/B9780124095489103793?via\%3Dihub (accessed on 31 October 2021).

24. Seeruttun, S.; Crossley, C.P. Use of digital terrain modelling for farm planning for mechanical harvest of sugar cane in Mauritius. Comput. Electron. Agric. 1997, 18, 29-42. [CrossRef]

25. Hu, Y.; Schneider, V.; Kuhn, B.; Guo, S.; Kuhn, N.J. Capturing the Scale Dependency of Erosion-Induced Variation in $\mathrm{CO}_{2}$ Emissions on Terraced Slopes. Front. Environ. Sci. 2021, 9, 211. [CrossRef]

26. Vyhláška Ministerstva Pôdohospodárstva SR č. 38/2005 Z.z. o Určení Hodnoty Pozemkov a Porastov na Nich na účely Pozemkových úprav. Available online: https:/ / www.slov-lex.sk/pravne-predpisy/SK/ZZ/2005/38/20050215 (accessed on 23 June 2021).

27. Bezák, P.; Mitchley, J. Drivers of change in mountain farming in Slovakia: From socialist collectivisation to the Common Agricultural Policy. Reg. Environ. Chang. 2014, 14, 1343-1356. [CrossRef]

28. Džatko, M.; Sobocká, J. The Guidebook for Bonited Soil-Ecological Units Using; VÚPOP: Bratislava, Slovakia, 2009. (In Slovak)

29. Muchová, Z.; Raškovič, V. Fragmentation of land ownership in Slovakia: Evolution, context, analysis and possible solutions. Land Use Policy 2020, 95, 104644. [CrossRef]

30. Hartvigsen, M.B. Experiences with Land Consolidation and Land banking in Central and Eastern Europe after 1989. (26 ed.) Food and Agriculture Organization of the United Nations. Land Tenure Working Paper Series. 2015. Available online: https://vbn.aau. dk/ws/files/208239365/Hartvigsen_2015_Land_Tenure_Working_Paper_26_land_consolidation_and_land_banking_pdf (accessed on 23 June 2021).

31. Food and Agriculture Organization of the United Nations (UN FAO). Operations Manual for Land Consolidation Pilot Projects in Central and Eastern Europe; UN FAO: Rome, Italy, 2004. Available online: http:/ / www.fao.org/3/ai142e/ai142e.pdf (accessed on 23 June 2021).

32. Scown, M.W.; Brady, M.V.; Nicholas, K.A. Billions in Misspent EU Agricultural Subsidies Could Support the Sustainable Development Goals. One Earth 2020, 3, 237-250. [CrossRef] [PubMed]

33. SHMI (Slovak Hydrometeorologic Institute). Climate Atlas of Slovakia; Slovak Hydrometeorologic Institute: Banská Bystrica, Slovakia, 2015; p. 228.

34. Dianiška, J. Rezortná čast' štátneho informačného systému rezortu pôdohospodárstva Slovenskej republiky. In Štátny Informačný Systém a Armáda Slovenskej Republiky; Topografický ústav Armády SR: Banská Bystrica, Slovakia, 1999; pp. $43-49$.

35. Bielek, P.; Čurlik, P.; Fulajtar, E.; Houskova, B.; Ilavska, B.; Kobza, J. Soil Survey and Managing of Soil Data in Slovakia. In Soil Resources of Europe, 2nd ed.; Jones, R.J.A., Houšková, B., Bullock, P., Montanarella, L., Eds.; European Soil Bureau Research Report No.9, EUR 20559 EN; Office for Official Publications of the European Communities: Luxembourg, 2005; pp. 317-329.

36. Muchová, Z.; Leitmanová, M.; Petrovič, F. Possibilities of optimal land use as a consequence of lessons learned from land consolidation projects (Slovakia). Ecol. Eng. 2016, 90, 294-306. [CrossRef]

37. Zákon č. 220/2004 Z.z. o Ochrane a Využívaní Pol'nohospodárskej Pôdy a o Zmene Zákona č. 245/2003 Z. z. o Integrovanej Prevencii a Kontrole Znečist'ovania Životného Prostredia a o Zmene a Doplnení Niektorých Zákonov. Available online: https: / / www.slov-lex.sk/pravne-predpisy/SK/ZZ/2004/220/20180901.html (accessed on 23 June 2021).

38. Zákon NR SR č. 162/1995 Z.z. o Katastri Nehnutel'ností a o Zápise Vlastníckych a Iných Práv k Nehnutel'nostiam (Katastrálny Zákon). Available online: https:/ / www.slov-lex.sk/pravne-predpisy/SK/ZZ/1995/162/20191001 (accessed on 23 June 2021).

39. Feriancová, L'.; Gažová, D.; Hrebíková, D.; Jamečný, L’; Kočík, K.; Mišíková, P.; Mišovičová, R.; Ot’ahel', J.; Pauditsova, E.; Ružička, M.; et al. Krajinné Plánovanie; Finka, M., Kozová, M., Pauditšová, E., Eds.; Slovenská Technická Univerzita: Bratislava, Slovakia, 2010.

40. Šinka, K.; Muchová, Z.; Konc, L'. Geografické Informačné Systémy v Priestorovom Plánovaní; Slovenská Pol'nohospodárska Univerzita v Nitre: Nitra, Slovakia, 2015.

41. Zevenbergen, L.W.; Thorne, C.R. Quantitative analysis of land surface topography. Earth Surf. Process. Landf. 1987, 12, 47-56. [CrossRef] 
42. Vilar, L.; Garrido, J.; Echavarría, P.; Martínez-Vega, J.; Martín, M.P. Comparative analysis of CORINE and climate change initiative land cover maps in Europe: Implications for wildfire occurrence estimation at regional and local scales. Int. J. Appl. Earth Obs. Geoinf. 2019, 78, 102-117. [CrossRef]

43. Komplexná Pozemková Reforma Ako Nutná Podmienka Obnovy Hospodárstva SR. Available online: http://www.kpu.sk/sites/ default/files/pozemkova_reforma_2020_v10_8.pdf (accessed on 10 September 2021). 